In New technologies in aquaculture:

Improving production efficiency, quality and

environmental management

July 2009, $1232 \mathrm{p}$.

Edited by G Burnell, University College Cork, Ireland

and G Allan, NSW Department of Primary Industries,

Australia

Woodhead Publishing Series in Food Science,

Technology and Nutrition No. 178

(c) 2009 Woodhead Publishing Limited

\title{
Monitoring viral contamination in shellfish growing areas
}

\author{
Françoise S. Le Guyader ${ }^{1}$, Monique Pommepuy ${ }^{2}$ and \\ Robert L. Atmar ${ }^{3}$
}

\begin{abstract}
${ }^{1}$ Laboratoire de Microbiologie, IFREMER, BP 21105, 44311 Nantes cedex 03, France Phone: 3324037 4052, fax: 3324047 4073, e-mail: sleguyad@ifremer.fr

${ }^{2}$ Laboratoire de Microbiologie, IFREMER, BP 70, 29280 Plouzané, France.

Phone: 3329822 4339, fax: 3329822 4594, e-mail: pommepuy@ifremer.fr

${ }^{3}$ Departments of Medicine and Molecular Virology \& Microbiology, Baylor College of Medicine, 1

Baylor Plaza, MS BCM280, Houston, TX 77030, USA

Phone: 1 (713) 798 6849, fax: 1 (713) 798 6802, e-mail: ratmar@bcm.edu
\end{abstract}

\begin{abstract}
:
Human and animal fecal wastes and urine contain a large number of different viruses that can enter the environment through the discharge of waste materials from infected individuals. Despite the high diversity of viruses that are introduced into the environment by human fecal pollution, only a few have been recognized to cause disease in association with consumption of contaminated shellfish. Viruses are present in shellfish in very low numbers. Nevertheless, they are present in sufficient quantities to pose a health risk as presented above. This low level of contamination has made it necessary to develop highly sensitive viral extraction methods to ensure virus recovery from shellfish tissues. The most common route for accidental contamination is after heavy rainfall, leading to overflow and release of untreated sewage into the aquatic environment. To limit shellfish contamination the most desirable and effective option is to reduce the viral input.
\end{abstract}

Keywords: human enteric viruses, shellfish, sewage, persistence, flux 
Introduction

1 Source of pollution.

1.1 Human enteric viruses.

1.2 Animal viruses, potential zoonotic viruses.

1.3 Example of outbreaks with a special interest on the source of virus contamination.

2 Methods.

2.1 Rapid review.

2.2 Quantification.

3. Input and flux.

3.1 Seasonal outbreaks.

3.2 Animal output.

3.3 Concentrations from sewage and rivers.

3.4 Flux calculation from sewage

3.5 Surface water

3.6 Potential indicators: phages, animal markers.

4. Strategies for reducing contamination.

4.1 Resistance of viruses

4.2 Persistence of viruses in shellfish tissues

4.3 Depuration

4.4 Other issues

5. Perspectives 
Shellfish have been identified as a vector for human enteric pathogens for more than 150 years. Shellfish filter large volumes of water during their feeding, and in the process they concentrate small particles containing micro-algae and microorganisms. The practice of consuming either raw or undercooked shellfish can lead to transmission of disease caused by human pathogens present in the shellfish. During the 1800 s, outbreaks of typhoid fever and cholera were associated with shellfish consumption (Richards, 1985). Contamination of shellfish-growing waters with human sewage was recognized as a contributing cause of the outbreaks, leading to the development of bacteriologic criteria to assess the impact of sewage on shellfish and shellfish-growing waters.

Most countries have endorsed sanitary controls on live bivalve shellfish. In the European Union, these are covered by Council Directive 91/492/EEC (Anonymous, 1991) and in the United States, by interstate trading agreements set out in the Federal Drug Administration National Shellfish Sanitation Program Manual of Operations (Anonymous, 1993). These regulations cover similar ground on the requirements for harvesting area classification, depuration, relaying, analytical methods, and provisions for suspension of harvesting from classified areas following a pollution or public health emergency. The legislation also requires that third country imports into the EU and US have to be produced under the same standard as domestic products. Exporting nations therefore have developed programs for compliance with the regulations of their target export markets.

A major weakness of these controls is the use of traditional bacterial indicators of fecal contamination, such as the fecal coliforms or $E$. coli, to assess contamination and hence implement the appropriate control measures. Fecal indicators are either measured in the shellfish themselves (EU requirement) or in the shellfish growing waters (US FDA requirement). Levels of $E$. coli are used to categorise harvesting areas and prescribe levels of treatment required before they can be sold to consumers. These controls led to a siginficant decrease in the number of shellfish-associated outbreaks of bacterial infection, but a new problem emerged. Outbreaks of nonbacterial gastroenteritis and infectious hepatitis were recognized to be associated described in association with shellfish consumption (Richards, 1987). Several reports described a lack of correlation between bacterial indicator microorganisms and viruses, and pathogenic viruses may be detected in shellfish from areas classified as suitable for commercial exploitation using fecal coliform criteria (Abad et al., 1997; Bosch et al., 2001; Butt et al. 2004; Le Guyader et al., 2006, 2008). A number of examples of trans-national outbreaks have recently been reported following trade between EU Member States (Le Guyader et al. 2006), and importation of shellfish from third countries into the EU and the US (Bosch et al., 2001; Butt et al., 2004). In addition, the practice of depuration, a process by which shellfish "purify" themselves of enteric bacteria by filtering clean waters, failed to eliminate the risk of viral mediated disease (Richards et al. 1988). Given the failure of the current arrangements to fully protect public health there is a clear need to develop better approaches to controlling this problem.

European shellfish trade totals $460 \mathrm{M} €$ per year, and increases by approximately $7 \%$ each year. The European production represents more than a third of the worldwide shellfish production (i.e., in 1991, 180000 tons of live weight: $72 \%$ of farmed bivalves, $28 \%$ wild Eurostat data) and 8500 companies currently employ around 23000 workers. This activity is one of the major sources of employment in coastal areas (Ireland, France, Spain, The Netherlands). The costs of outbreaks of shellfish-associated viral disease have not been clearly defined, but they are likely to be substantial. In the USA, foodborne diseases are a major cause of morbidity and hospitalization, with about 325000 hospitalizations and 5000 deaths per year (Butt et al., 2004). Among the 76 million estimated cases of foodborne disease, $10-19 \%$ of those for which a vehicle of transmission is identified involve seafood; half of these are caused by viruses, and half of the illnesses are associated with shellfish consumption (Mead et al., 1999; Butt et al., 2004). In countries with higher seafood consumption, or where seafood is traditionally eaten raw, a larger percentage of foodborne illnesses are due to seafood consumption. For example, in Japan as much as $70 \%$ of foodborne illness is associated with seafood consumption (Butt et al., 2004). 


\section{Source of pollution}

\subsection{Human enteric viruses.}

Human and animal fecal wastes and urine contain a large number of different viruses that can enter the environment through the discharge of waste materials from infected individuals. These enteric viruses cause a wide spectrum of illnesses in man including hepatitis, gastroenteritis, meningitis, fever, rash, and conjunctivitis. A brief description of the principal viruses that have been characterized either in outbreaks or in field studies is given below and their different characteristics are described Table 1.

\section{Hepatitis A virus (HAV)}

Infectious hepatitis, caused by the hepatitis A virus, is one of the most serious illnesses transmitted by shellfish. The hepatitis $A$ virus belongs to the genus Hepatovirus of the family Picornaviridae, and is very stable in the environment, remaining viable for up to several weeks in water or on fomites (Abad et al., 1994; Arnal et al., 1998; Hollinger and Emerson 2007). Hepatitis A virus infection has a long incubation period and is generally asymptomatic or associated with a mild illness in young children, while in older children and adults the illness is characterized by jaundice in more than $70 \%$ of individuals (CDC, 2006). There is only a single serotype, and an effective vaccine is available for prevention of infection (CDC, 2006).

\section{Noroviruses}

Noroviruses are the most common infection currently associated with shellfish consumption. Norovirus is a genus in the family Caliciviridae, and the genus is divided into 5 genogroups (Zheng et al., 2006). Genogroups I, II and IV contain human strains, and the genogroups are further subdivided into genotypes based upon analyses of the amino acid sequence of the major capsid protein, VP1. Norovirus infection causes gastroenteritis characterized by the symptoms of vomiting and diarrhoea (Atmar and Estes, 2006). The prevalence of vomiting along with the short incubation period (1-2 days) and short clinical illness (1-3 days) has been used epidemiologically to identify probable outbreaks of norovirus-associated gastroenteritis (Kaplan et al., 1982; Turcios et al. 2006). The virus is stable in the environment, and the infectious dose is estimated to be less than 20 virions (Teunis et al. 2008).

Noroviruses are the major cause of epidemic non bacterial gastroenteritis worldwide and have been identified as the cause of $73 \%$ to more than $95 \%$ of outbreaks (Atmar and Estes, 2006). Mead and colleagues estimated that there are 23 million norovirus infections per year in the United States, and these viruses constitute $60 \%$ of the illness burden caused by known enteric pathogens (Mead et al. 1999). Although some studies provide a good indication of the substantial illness burden that results from NoV infection, the true extent of disease may still not be fully known (Patel et al. 2008).

Rotavirus

Rotaviruses are the main etiological agent of viral gastroenteritis in infants and young children. They constitute a genus in the Reoviridae family (Estes and Kapikian, 2007). In developing countries the burden of rotavirus disease in children under 5 years of age has been estimated to be over 125 million cases annually, of which 18 million are severe cases (nearly half a million deaths) (Oh et al., 2003; Parashar et al., 1998). In the developed world, it remains an important cause of morbidity and of hospitalization in young children and they are also increasingly recognized as a cause of infectious diarrhea in adults as well (Anderson and Weber, 2004).

\section{Astrovirus.}

Astroviruses classified in genus Mamastrovirus (human and animal strains) within the family Astroviridae (Mendez and Arias, 2007). In most species astrovirus are found in association 
with gastroenteritis, although other manifestations have been described in avian species (Mendez and Arias, 2007).

\section{Enterovirus.}

Human enteroviruses belong to the genus Enterovirus in the Picornaviridae family. Poliovirus is a species within the Enterovirus genus and its three serotypes each can cause a devastating neurological disease for which, despite vaccination campaigns, the goal of global eradication has not yet been completed. Other enterovirus species and serotypes cause a variety of other clinical syndromes, including respiratory infections, haemorrhagic conjunctivitis, and myocarditis (Pallansch and Roos, 2007).

Aichi virus.

Aichi virus belongs to the Kobuvirus genus in the Picornaviridae family. Aichi virus was identified in several other outbreaks in Japan as a cause of gastroenteritis associated with shellfish consumption (Yamashita et al., 2000) and was recently recognized in an oysterrelated outbreak in Europe in 2006 (Le Guyader et al. online first).

\section{Adenovirus.}

Human adenoviruses belong to the genus Mastadenovirus in the Adenoviridae family (Wold and Horwitz, 2007). There are 6 species of human adenoviruses, and members of species $F$ (formerly called subgroup F), consist of two serotypes, Ad40 and Ad41 causing diarrhoea and also referred to as enteric adenoviruses.

\section{Hepatitis E virus}

Hepatitis $E$ virus, a member of the Hepeviridae family. It is the primary cause of enterically transmitted non-A non-B hepatitis in tropical and subtropical developing countries, and it has an associated mortality rate of up to $20 \%$ in pregnant women (Lu et al. 2006).

\subsection{Animal viruses, potential zoonotic viruses.}

A number of enteric viruses inducing gastroenteritis in humans have also been identified in animals. The predominant animals involved are porcine and bovine species. These observations raise the possibility that zoonotic transmission may occur. Such transmission has been best demonstrated to occur among rotaviruses. Bovine-human and porcine-human group A rotavirus reassortants have been identified in India, Italy, Slovenia, and Brazil, and a porcine group C rotavirus was identified in a child in Brazil (Estes and Kapikian 2007; Martella et al. 2008; Gabbay et al. 2008; Steyer et al. 2008).

There is also the potential for zoonotic transmission of noroviruses. Several porcine genogroup II norovirus strains have been characterized, and based upon the sequences of their major capsid protein (VP1) they have been classified in genotypes that are distinct from those of human strains (Zheng et al. 2006; Wang et al. 2005). Bovine strains are even less related to human strains and have been classified in a separate genogroup (genogroup III) (Oliver et al. 2003). However, the ability of human strains to replicate in pigs and cattle (Cheetham et al. 2006; Souza et al. 2008) has been demonstrated experimentally, and a recent study from Canada reported the presence of human-like Gll.4 norovirus strains in pig feces and retail beef (Mattison et al. 2007). To date, no human infections with animal norovirus strains has been reported, but the simultaneous detection of human and animal enteric calciviruses in oysters samples collected from the markets suggests the potential for such infections to occur if humans can be infected with animal strains (Costantini et al., 2006; Symes et al., 2007). The significance of such an infection is the potential for the emergence of new strains through recombination events, as such events appear to be common among human strains (Bull et al. 2007). 
Enteroviruses are also important pathogens for cattle and swine and high concentrations of these viruses may be detected in surface waters (Fong and Lipp, 2005). As for norovirus, shellfish contamination with animal and human enterovirus strains was demonstrated in oysters samples collected in an area impacted both with human and bovine sewage (Dubois et al., 2004). The stringency of the host specificity among human and bovine strains suggest that they can be good indicators for identifying human and non-human sources of fecal contamination of natural waters (Fong and Lipp, 2005).

Hepatitis $\mathrm{E}$ virus is a potential emerging pathogen, and evidence of its global spread as a cause of disease in man is increasing. Clear demonstration of sequence homology between strains detected among swine or other domestic animals have now been made in several countries (Rutjes et al. 2007, Renou et al. 2007,Ward et al. 2008, Kaci et al. 2008). However, transmission seems to occur primarily through direct contact with infected animal or food consumption (e.g., pig liver) (Renou et al. 2007, Lewis et al. 2008). Shellfish consumption has been reported as a risk factor for hepatitis $E$ virus infection, but additional studies are needed to establish this link (Cacopardo et al., 1997; Koizumi et al., 2004).

\subsection{Examples of outbreaks with a special emphasis on the source of virus contamination.}

Despite the high diversity of viruses that are introduced into the environment by human fecal pollution, only a few have been recognized to cause disease in association with consumption of contaminated shellfish. Potential explanations, for this observation, include a lack of susceptibility of the persons consuming the shellfish to these viruses (i.e., pre-existing immunity), a requirement for exposure to higher doses than are present in the shellfish to establish infection, and a lack of recognition of disease either through under-reporting or the unavailability of sensitive diagnostic assays.

The instigation of regulations to specify acceptable levels of bacterial enteric pathogens in shellfish tissues or in shellfish growing waters in Europe (European regulation, 91/492/EC) and the United States (National Shellfish Sanitation Program) and improvements in sewage waste treatment procedures were followed by the virtual elimination of shellfish-associated outbreaks of typhoid fever and cholera in the United States (Richards, 1985; Rippey, 1994). However, as shellfish-associated bacterial infection declined, outbreaks of nonbacterial gastroenteritis and infectious hepatitis were described in association with shellfish consumption (Butt et al., 2004). In many instances, the shellfish and shellfish-growing waters met regulatory criteria for fecal bacterial levels, suggesting an accidental contamination event rather than exposure to a continuous sewage discharge.

The most common route for accidental contamination is after heavy rainfall, leading to overflow and release of untreated sewage into the aquatic environment. As mentioned above, untreated sewage is likely to be heavily contaminated by enteric viruses. Frequently the source of accidental events for shellfish contamination cannot be traced, but a number of reports have been able to elucidate the cause of human fecal pollution. For example, several clusters of gastroenteritis occurred in six states in the USA and were linked to oyster consumption. The oysters implicated in the outbreaks were all traced back to a single harvest area, and the epidemiological investigation showed that the outbreak resulted from disposal of human diarrheal stool from a single ill individual directly into the waters over the shellfish bed (Kohn et al., 1995). Another example was a large oyster-associated gastroenteritis outbreak that affected approximately 2000 persons during the summer of 1978 in Australia (Murphy et al., 1979). This outbreak was linked to sewage contamination of the oyster harvesting area near Sydney following a heavy rainfall. Runoff from heavy spring rains were also suspected to be responsible for 103 clusters of norovirus gastroenteritis involving more than 1000 persons after clam or oyster consumption in New York State in 1982 (Morse et al., 1986). In the south of France, heavy rainfall and sewage treatment plant 
failure were twice implicated as the cause of large gastroenteritis outbreaks due to consumption of oysters harvested from a single lagoon (Le Guyader et al., 2006a; 2008).

The long incubation period of hepatitis A complicates linkage of this agent to particular food exposure incidents. However, linkage is still possible during large incidents. In 1988 in Shanghai, China, almost 300,000 hepatitis A cases were traced to the consumption of clams harvested from a sewage-polluted area (Halliday et al., 1991). A sizeable hepatitis A outbreak in the USA in 1973 was linked to Louisiana oysters. The harvesting areas were flooded by the Mississippi River, and there was evidence of sewage contamination based upon elevated fecal coliform levels that led to closure of the oyster beds. Subsequently, the oyster beds were reopened to harvesting, but apparentlythe hepatitis A virus was retained in shellfish for at least 6 weeks following the contamination event. At the time of harvesting, oysters were fully compliant with the US sanitation program standard but still contaminated with the virus (Mackowiak et al., 1976). Many other hepatitis A outbreaks linked to bivalve shellfish have been reported but the initiating fecal contamination event has been generally difficult to identify due to the protracted incubation period for this disease (Bosch et al. 2001).

In summary, where a cause is ascribed, most contamination accidents are linked to failures or bypassing of treatment processes, often due to heavy rainfall (figure 1). The problem is that heavy rain causes the storage capacity of the sewage treatment plant to be exceeded. In combined sewer and rainfall systems this leads to storm spills. Such discharges result in the release of untreated effluent heavily contaminated with microorganisms. This may be particularly true during the 'first flush'. Other causes are flooding of harvest areas with contaminated river water and disposal of faeces from infected individuals on boats. It is interesting to note that although the efficiency of sewage treatment processes at fully removing viruses from effluents can be questioned, such effluents are not usually associated with bivalve mollusc disease incidents. However, because most enteric viruses retain their viability in the environment, they can persist for a much longer time in the marine environment than bacterial indicators - up to weeks or months (Wait et al., 2001; Lipp et al., 2002; Griffin et al., 2003). In addition, viral particles have been noted to persist for months in shellfish tissues, either via ionic binding or specific attachment (Burkhardt and Calci, 2000; Loisy et al. 2005a, Le Guyader et al. 2006b).

\section{Methods}

\subsection{Rapid review.}

Viruses are present in shellfish in very low numbers. Nevertheless, they are present in sufficient quantities to pose a health risk as presented above. This low level of contamination has made it necessary to develop highly sensitive viral extraction methods to ensure virus recovery from shellfish tissues. The observation that viruses are concentrated in digestive diverticulum tissues led to the development of a method that represented a major step in the improvement of extraction methodologies (Metcalf et al., 1980; Atmar et al., 1995). This observation was subsequently confirmed by detection of hepatitis A virus (HAV) (Romalde et al., 1994) as well as through the tissue-specific quantification of infectious enteric adenoviruses and rotaviruses in mussels previously contaminated by bioaccumulation of such viruses and similarly of Norwalk virus in oysters and clams (Abad et al., 1997; Schwab et al., 1998). Analysis of digestive tissues provides several advantages, including increased sensitivity, decreased processing time and decreased interference with RT-PCR by inhibitory substances (Atmar et al., 1995). Focusing the analysis of shellfish on the digestive tissues enhances assay performance by eliminating tissues (i.e. adductor muscle) that are rich in inhibitors (Atmar et al. 1995). The digestive tissues represent about one tenth of the total animal weight for oysters and mussels. With the exception of small species, such as clams or 
cockles, in which dissection may be technically difficult, most of recent methods are based on dissected tissues and thus will be discussed here.

Extraction of enteric viruses from shellfish is based on several steps: virus elution from shellfish tissues, recovery of viral particles, and then virus concentration. The weight analyzed generally ranges from 1.5 to $2 \mathrm{~g}$ of digestive tissues. Some recent methods propose larger weights for the first step but thereafter analyze only a fraction of the extracts (Boxman et al., 2006). Viruses are eluted from shellfish digestive tissues using various buffers (i.e. chloroform-butanol or glycine) before being concentrated either by polyethylene glycol precipitation or ultracentrifugation (Atmar et al., 1995; Nishida et al., 2003; Myrmel et al. 2004; Milne et al. 2007). Direct lysis of virus particles has also been used, including methods utlizing proteinase $\mathrm{K}$ or Trizol to destroy shellfish tissues or Zirconia beads and a denaturing buffer for virus and/or nucleic acid elution (Lodder-Verschoor et al., 2005; Jothikumar et al., 2005; Kittigul et al. 2008; Umesha et al. 2008; Lowther et al. 2008).

In addition to the in-house protocols that have been used for nucleic acids extraction and purification (le Guyader and Atmar, 2007), a number of commercial kits can also be successfully applied to accomplish this task. Advantages of the commercial kits used for nucleic acid purification include their reliability, reproducibility and ease of use. Most of these kits are based on guanidium lysis followed by capture of nucleic acids on columns, beads or silica (Nishida et al. 2003; Lodder-Verschoor et al. 2005; Costafreda et al., 2006; de RodaHusmann et al., 2007; Kingsley 2007; Milne et al., 2007; Fukuda et al.,2008; Nenonen et al. 2008; Umesha et al., 2008).

One of the goals of extraction methods is to remove inhibitors of the RT and PCR reactions sufficiently to allow detection of viral nucleic acids. Polysaccharides present in shellfish tissue are at least one substance that can inhibit the PCR reaction (Atmar et al., 1993). Elimination of inhibitors is difficult to evaluate and depending on the time of the year and shellfish life, different compounds may be present (Di Girolamo et al. 1977; Burkhardt and Calci, 2000). Internal amplification control standards are used to detect the presence of significant sample inhibition, and the amount and frequency of sample inhibition has varied depending upon the shellfish tissue being analyzed (Atmar et al.,1995; Schwab et al., 1998; Le Guyader et al., 2000). Recent advances in food virology re-enforce the need of harmonization of methods as well as addressing quality assurance and quality control (Pinto and Bosch, 2008).

The addition of an external virus to a shellfish sample has been proposed as a control to evaluate the extraction efficiency of molecular virus detection methods (Costafreda et al., 2006; Nishida et al., 2007; Lowther et al., 2008). An ideal candidate would have the following properties: (1) it would be an encapsidated RNA virus with properties similar to the enteric viruses contaminating shellfish, (2) it would normally not be present in field samples (thus RNA phages may be problematic), and (3) it would be non-pathogenic. Based on these considerations Costafreda et al. (2006), proposed to use a mengovirus strain $\mathrm{MC}_{0}$ as a control for extraction efficiency. Mengovirus, a Picornaviridae family member, was initially proposed as a control in validation studies of HAV removal in blood products manufacturing by several agencies such as the European Agency for the Evaluation of Medicinal products or the American Food and Drug Administration (Pinto and Bosch, 2008). Advantages of mengovirus are that it is unlikely to naturally contaminate shellfish, it is non-pathogenic for humans and it can be grown in cell culture. The use of a single extraction control for different enteric viruses that may be detected in shellfish or other type of food is also considered to be important for method standardization (European working group CEN/Tag4) and for comparisons between different laboratories.

Since the most important shellfish-borne viral pathogens (enteric hepatitis viruses $A$ and $E$ and noroviruses) are either non-culturable or grow only poorly in cell culture, RT-PCR and real-time RT-PCR have become the methods of choice for their detection. In addition to the problems posed by the presence of inhibitory substances in samples, there are other 
difficulties encountered when molecular analyses are performed for the detection of viruses in shellfish samples. These include low virus concentrations in the sample and genomic diversity of the contaminating viruses. The extraction-concentration procedure is not virusspecific, allowing the nucleic acid of several viruses to be extracted simultaneously. RT-PCR must be performed under stringent conditions and confirmed by hybridization. A number of reviews on RT-PCR methods are now available that address issues related to these methods, including assay specificity and sensitivity (Wyn-Jones, 2007; Le Guyader and Atmar, 2007).

Real-time PCR assays allow the combination of RT, PCR and confirmatory hybridization assays in a single well, and these assays are now being used to detect enteric viruses in shellfish (Nishida et al., 2003; Loisy et al., 2005b; Jothikumar et al., 2005; Costafreda et al., 2006; Lowther et al. 2008). This technology significantly shortens the time needed for virus detection by removing the need for gel electrophoresis and the additional hybridization step. When extraction, RT and PCR efficiencies are measured, virus quantification in the sample can be estimated (Costafreda et al., 2006). The efficiency of the virus nucleic acids extraction is evaluated through the use of a model virus (as described above) while the efficiency of the RT-PCR reaction must be tracked by amplification of a RNA standard using the same combination of primers and probe used for virus detection (Pinto and Bosch, 2008). Such internal RNA controls have also been used for the detection of amplification inhibitors in qualitative assays (Schwab et al., 1998; Le Guyader et al., 2003).

\subsection{Quantification.}

The development of quantitative molecular assays for the analysis of shellfish has allowed estimates of the level of virus in naturally contaminated shellfish. However, relatively few data are currently available in this area. One report estimated the amount of HAV in coquina clams implicated in an outbreak to be between $7.5 \times 10^{3}$ to $7.9 \times 10^{5}$ genome copies per $\mathrm{g}$ of digestive tissues (Coastafreda et al., 2006). Another recent report used a semi-quantitative approach for norovirus detection to compare the levels of virus contamination between sites without describing the amount of shellfish analyzed (Lowther et al., 2008). Japanese investigators estimated the levels of norovirus contamination in oysters collected from two areas range from $<100$ copies to $7.9 \times 10^{3}$ genome copies per $\mathrm{g}$ of digestive tissues in two consecutive studies (Nishida et al. 2003, 2007). These estimates did not include an adjustment for extraction efficiency, as proposed by Costafreda et al. (2006). Similar data have been obtained for the levels of norovirus contamination in oysters from France (Le Guyader et al., 2008). Quantitative estimates of norovirus contamination in shellfish implicated in outbreaks are even more uncommon. By using MPN PCR or real-time RT-PCR, about 100 copies of genome/g of digestive tissues were found in oysters in France (Le Guyader et al., 2003, 2006a, 2008). This level of contamination is sufficient to cause human infection based upon the low infectious dose of the Norwalk virus, prototype for norovirus, in a volunteer study (Teunis et al., 2008). The availability of quantitative assays offers the potential to perform risk assessments associated with the consumption of virus-contaminated shellfish.

\section{Input and flux}

\subsection{Seasonal outbreaks.}

The regular and predictable pattern of seasonal outbreaks dominates the epidemiology of many exclusively human pathogens (Dowell, 2001). The seasonal infection may vary between different pathogens, but the timing and characteristics of the annual outbreak of a single pathogen are remarkably consistent from year to year. It was shown that latitude has a clear influence on the timing and magnitude of outbreaks of rotavirus infections and poliomyelitis (Dowell, 2001). Data collected from different studies worldwide have also shown 
a clear seasonality for norovirus outbreaks. A clear peak of norovirus outbreaks occurs during cold weather months on several continents, with lack of UV, cold temperature, frequent run-off being some of the possible explanations of extensive transmission (Mounts et al., 2000). However, noroviruses continue to circulate endemically throughout the year, and although there is the theoretic possibility of zoonotic spread, currently there is no direct evidence of the existence of a reservoir for re-introduction into the human population (Lopman et al., 2008). Gastroenteritis from all causes predominates during colder months of the year but it does not disappear during summer (Dowell 2001; Lopman et al., 2008). It is now evident that some viruses may be detected all year long, either in sporadic cases of illness or in untreated sewage (da Silva et al., 2007, Patel et al., 2008). The amount of virus shed by ill people may be very high (Atmar et al., 2008) (Table 2). Importantly postsymptomatic virus shedding may continue for some time, as demonstrated for enterovirus, hepatitis A, and norovirus (Pallansch and Roos, 2007; Hollinger and 2007; Atmar et al., 2008). For example, norovirus shedding in an experimental human infection model lasted a median of 28 days, with a range from 13 to 56 days, and most subjects were no longer symptomatic by day 4 (Atmar et al., 2008). These data suggest that the impact of continued virus shedding from ill and post-symptomatic patient on sewage may be very significant.

Enterically-transmitted hepatitis viruses are distributed worldwide with no clear season pattern. The endemicity in different parts of the world is closely linked to the level of socioeconomic development. In developing countries with poor sanitary and living conditions, transmission rates of HAV are high with a large number of subclinical cases shedding high concentration of viruses into the environment (Aggarwal and Naik, 2008). In contrast, the levels of HAV endemicity and transmission rates are much lower in developed countries, and detection of viruses in the environment is less common so that introduction into the environment may be limited in time and localization (Pinto and Saiz, 2007).

\subsection{Animal output.}

As noted earlier, some enteric viruses can also be detected in animals. These animal infections can lead to contamination of the environment and can confound the identification of human strains, depending on the detection methods that are used. For example, rotavirus is a pathogen for young calves and pigs. Calves can excrete very high levels of rotavirus (up to $10^{11}$ viral particles/g of stool) for a week or longer. Most of the strains implicated in bovine disease belong to group A rotavirus, the most common cause of human disease (Dhama et al. 2008). Group A rotaviruses have also been detected in equine, swine, ovines, and caprines, and pet dogs and cats may also be infected with these viruses (Dhama et al., 2008).

Norovirus also infect other species including swine and cattle. The prevalence of norovirus infection in these animals has varied in studies from different countries. One in 17 porcine fecal samples from Hungary was found positive for norovirus (Reuter et al., 2006) while in Italy none of the 209 stool was positive for norovirus (Martella et al., 2008). In contrast, $2 \%$ of pigs stool samples in The Netherlands were NoV-positive (van der Poel et al., 2000), and the prevalence of porcine norovirus on farms in the United States was reported to range between 3 and $40 \%$ (Wang et al., 2006). In Canada, about 25\% of swine fecal samples were found positive while only $1.6 \%$ of bovine fecal samples contained noroviruses (Mattison et al., 2007). Bovine norovirus have also been detected in $9.1 \%$ of diarrheic calves in Korea (Park et al. 2008). Other studies have identified bovine noroviruses in $72 \%$ of veal calves from the US (Smiley et al., 2003), in approximately a third of veal calf farm samples from The Netherlands (van der Poel et al., 2000) and in $8 \%$ of calf diarrhoea samples from the United Kingdom (Oliver et al., 2003).

3.3 Enteric viruses in sewage and rivers.

A review of available information in the literature on the fluxes of human enteric viruses discharged into the environment clearly shows that the presence of pathogens in waters 
reflects the epidemiology of these viruses in the human population (Rohayem et al., 2006; Myrmel et al., 2006; da Silva et al., 2007; Schawb, 2007). The lack of reliable quantification methods (such as cell culture) for many of the enteric viruses has precluded accurate quantitative analyses of these viruses from environmental samples. Although the development of quantitative molecular assays now offers the promise to generate such data, they can be impacted by many factors such as virus concentration efficiency and amplification efficiency which many investigators fail to consider. In addition, molecular assays cannot evaluate virus infectivity, since they detect both live and inactivated virions. Consequently the molecular assay may lead to an overestimate of the amount of infectious virus present in a sample (Richards, 1999; Gerba, 2007).

The concentration of noroviruses measured in natural waters and raw sewage has shown both regional and seasonal variability. In The Netherlands, noroviruses were detected on average at $2 \times 10^{5}$ PCR detectable units (PDU) /liter of raw sewage, with only one sample being negative (September) (Lodder and de Roda Husman, 2005). In the UK norovirus concentrations ranged from zero to $1.7 \times 10^{7} \mathrm{cDNA}$ copies/L and in Germany approximately $10^{6}$ copies/L were reported (Laverick et al., 2004; Pusch et al., 2005). Haramoto et al. (2006) described seasonal differences in norovirus concentrations in untreated sewage, from a peak of $1.9 \times 10^{6}$ RNA copies/L in December to a low of $2.4 \times 10^{3}$ copies/L in September. Similarly, da Silva et al. (2007) and Katayama et al. (2008) reported higher noroviruses concentrations (about $10^{5}$ genomes copies/L for both studies) in untreated sewage during winter months compared to spring or summer. All of these studies found both genogroup I and genogroup II norovirus strains. Genogroup II strains cause the large majority (80 to $90+\%$ in most studies) of clinical cases seen by physicians (Atmar and Estes, 2006; Lopman et al. 2008). The consistent detection of genogroup I strains in raw sewage genogroup I demonstrates that these viruses are circulating in the population (Haramoto et al., 2006; van der Berg et al., 2005; da Silva et al., 2007; Katayama et al., 2008).

Rotaviruses and enteroviruses are also detected in raw sewage in approximately the same range of concentrations (Pusch et al., 2005; Lodder and de Roda Husman, 2005). Astrovirus may be detected as higher concentrations (up to $10^{8}$ genome copies/l) (Pusch et al., 2005; Le Cann et al., 2004). The data for wastewater samples may reflect the presence of strains that circulate more widely in the population and as such may be a powerful ad useful tool for public health surveillance (Hovi, 2006).

Despite treatment of sewage to remove bacterial and viral pathogens, treated wasterwater contains enteric viruses that can potentially contaminate the environment (Table 3 ). Concentrations of hundred to thousands genome copies per liter of treated wastewater can be detected, and seasonal variability occurs similar to that seen for untreated sewage. Several studies have observed a higher frequency of genogroup I (GI) norovirus strains in treated effluent compared to genogroup II strains (van der Berg et al., 2005; Myrmel et al., 2006; La Rosa et al., 2007; da Silva et al., 2007). Haramoto et al. (2006) even reported that all treated sewage samples were positive for $\mathrm{Gl}$. The reason why $\mathrm{Gl}$ noroviruses are more resistant to inactivation and removal during the sewage treatment process is not clear and should be studied in the future. Some differences in capsid proteins or binding properties may be one interesting hypothesis to analyze. That GI noroviruses are more often implicated in shellfish- and water-related outbreaks than GII may also be evidence in favor of higher resistance to inactivation in the environment (Lopman et al., 2004; Blanton et al., 2006). Overall noroviruses are found in concentrations ranging from undetectable to $10^{6}$ genome copies/l of treated wastewater (Table 3).

The efficacy of different wastewater treatments for norovirus removal from wastewaters has varied from 0.5 to $4 \log _{10}$ (Table 4 ). One of the most promising approaches utilizes ultrafiltration, such as MBR technology operating with biological treatment as well as physical separation of particles. Sano et al. (2006) reported complete elimination of noroviruses from 
sewage sludge and treated water, with greater than $4 \log _{10}$ reduction values by ultrafiltration. The use of microfilters with pore sizes as large as 0.45 microns also effectively removed virus, with $\log _{10}$ reduction values of more than 3.9 for sewage sludge and 2.9 for treated water. The microfilter membranes have permeability that is much larger than the diameter of viruses but can be effective since the viruses are embedded in or adsorbed to solids. Nevertheless, viral particles may be detected in effluents after treatment with microfilters with larger pore sized, implying that such membranes are not an absolute barrier for the passage of viruses (Ueki et al., 2005; da Sylva et al., 2007).

Another approach is to utilize techniques that enhance the effectiveness of ultraviolet disinfection. Norovirus appears to be quite resistant to UV radiation (Ottoson et al., 2006; Hijnen et al. 2006) but genome destruction may be achieved using a highly photocatalytic material $\mathrm{TiO}_{2}$ (Titanium dioxide), in conjunction with UV (Kato et al., 2005). Addition of low concentration of $\mathrm{TiO}_{2} \mathrm{U}$ particles also increased the rate of inactivation of phage MS2, although the effect on murine norovirus (a surrogate for human noroviruses) was less (Lee et al. 2008).

\subsection{Flux calculation from sewage.}

Information on virus sources and virus levels in raw or treated wastewaters can be used to estimate the quantities of virus discharged into the environment. Relatively few data are available to allow the calculation of "virus base-flow" or "event-flow" discharges in river or in estuaries. Nevertheless recent data suggest that during non-epidemic periods less than $10^{3}$ $10^{4}$ genome copies/L of norovirus are present in treated wastewaters. During the epidemic period (winter) the concentration is probably 100- to 1000 -fold higher. The rate of reduction of virus concentrations through sewage treatment processes is almost constant and independent of the concentration of viruses of the effluent (Myrmel et al., 2006; daSilva et al. 2007; Katayama et al., 2008). These data imply that viruses are discharged into environmental waters with a seasonal profile and raises questions about the frequency and duration of such peaks and the importance and impact of storm events that result in failure in wastewater treatment during a high flow and epidemic period. In the absence of precise information, calculations from epidemiological data suggest that $10^{6}$ norovirus fluxes can be expected from a town of 60,000 population-equivalent when winter outbreaks are occurring (Pommepuy et al., 2004). Many environmental factors can have an impact, including currents, estuaries, and tide (Pommepuy et al. 2005). The persistence of viruses in the environment must be considered even in nonepidemic periods when risks of infection associated with shellfish consumption are estimated (Riou et al., 2007).

\subsection{Surface water.}

Viruses may be discharged into surface water from different sources, such as septic tank or sewer lines leaking, wastewater irrigation of sludge disposal. In a recent review, Gerba (2007) identified studies describing the occurrence of enteric viruses in surface freshwater and demonstrated that in all countries a number of different viruses can be detected. However it is clear that data are still limited and information on virus concentration and infectivity are often lacking.

Noroviruses are relatively resistant to inactivation compared to other enteric viruses, possibly explaining their predominant role in food-related outbreaks. Detection of infectious norovirus is not possible due to the lack of availability of an in vitro cell culture system or small animal model. Other culturable virus surrogates have been proposed to model virus persistence in environmental samples. Bae and Schwab (2008) used a murine norovirus strain to evaluate virus persistence in different types of surface waters compared with MS2 phage, poliovirus, and feline calicivirus in an infectivity assay. The murine norovirus infectivity persisted longer than feline calicivirus and as long as the other human norovirus surrogates. In addition, reduction of murine norovirus nucleic acids as measured by real-time RT-PCR was similar to that of a human norovirus strain in surface waters ( 0.08 and $0.09 \log _{10} /$ day, respectively) and 
in groundwaters (0.01 and $0.00 \log _{10} /$ day, respectively) (Bae and Schwab, 2008). Norovirus are detected in surface waters less frequently than in wastewaters, probably due in part to dilution or sedimentation mechanisms during transport in the rivers. The reported frequencies of norovirus detection has varied between studies from $5.8 \%$ in a Brazilian river to $53 \%$ in Japan (Haramoto et al., 2005; Miagostovich et al., 2008). Peak norovirus concentrations of up to $10^{4}$ genome copies/liter of surface waters have been reported, suggesting that the risk of infection can vary quantitatively as well as qualitatively (Lodder and de Roda Husman, 2005; Westrell et al., 2006). The other human enteric viruses can also be detected to various concentrations as noted in a recent review Gerba (2007). For example, hepatitis A virus is endemic in some Italian areas, and viral RNA has been detected at concentrations ranging from 75 to 730 genomes/L in Venetian canals (Rose et al., 2006).

Fluctuations in virus concentrations may result from a combination of different factors, such as sewer overflows leading to untreated water being discharged in rivers and run-off from pastures. Detection of short-term fluctuations is important to predict the risk for water contamination, but few data are available. A two-year study on the Meuse river in The Netherlands, found mean norovirus values to range from 4 to 4,900 genome copies/L (Westrell et al., 2006). Within the winter seasonal peak, quantitative and qualitative fluctuations of norovirus presence in the river waters occurred over varying lengths of time, and the highest concentrations could lead to significant contamination of drinking waters if water treatment measures failed. There are models to study the impact of river and wastewater discharges on coastal waters and shellfish quality (Pommepuy et al., 2005; Riou et al, 2007). However, these models, even though they appear to be useful, can be improved with additional information, including a larger input database, data on short-term fluctuation frequencies, and a better understanding of viral behavior and persistence in the environment (e.g., in sediments and shellfish).

\subsection{Potential indicators: phages, animal markers.}

The current regulatory controls in most countries rely on fecal pollution indicator organisms, such as E.coli, to assess microbiological hazards. Methods to detect E.coli are inexpensive, standardized and widely available (European regulation, 91/492/EC or United States National Shellfish Sanitation Program). However, it is clear now that fecal coliforms inadequately reflect the presence of human enteric viral contaminants (Butt et al., 2004). As no standardized methods are yet available for human enteric viruses in shellfish, a number of workers have proposed alternative indicators for better assessment of viral contamination. Various species of bacteriophages are some of the most frequently proposed indicators because of their physical and genomic similarity to human enteric viruses, their abundance in sewage effluents and the availability of simple methods for their detection. Male-specific RNA (F-RNA) bacteriophages have been proposed as a candidate indicator for water pollution (Havelaar et al., 1993). However, although F-RNA bacteriophages share physical and genomic properties with the human enteric viruses, their distribution (similar to fecal coliform bacteria) is not restricted to human effluents. Studies related to bivalve shellfish contamination by human enteric viruses and phages have shown variable results (Table 5). The F-RNA bacteriophage appears to perform best in sites that are consistently polluted. A number of studies have shown that F-RNA bacteriophages were not detected when human enteric viruses were present. For example, data collected in an European survey demonstrated that shellfish collected from southern Europe were negative for phages but contained human viruses (Formiga-Cruz et al., 2003). Similarly, a study from France reported that the detection of FRNA bacteriophages failed to predict the presence of human viruses (Miossec et al., 2001). A correlation was found between noroviruses and phage contamination of mussels in cold seawater, but more than half of the norovirus-positive samples were negative for FRNA phages and a positive FRNA phage result was less than twice as common in samples with norovirus than in these without norovirus, raising the question to use FRNA as an indicator (Myrmel et al., 2004). A one-year study in the Netherlands found phages were present in $67 \%$ of oyster samples analysed, but no pathogenic viruses such as norovirus or hepatitis A virus were identified in the shellfish 
(Lodder-Verschoor et al., 2005). A discrepancy level of $55 \%$ was observed between the detection of hepatitis $A$ virus and FRNA phages in association with a large outbreak of hepatitis A(184 human cases) from imported shellfish in the East of Spain in 1999 (Bosch et al., 2001). Phages may be used to classify areas for sanitary safety, but they have been unreliable indicators of virus-contamination of shellfish (Hernroth et al., 2002).

\section{Strategies for reducing contamination}

\subsection{Resistance of virus.}

Many human enteric viruses are resistant to inactivation or removal from the environment. Nenonen et al. (2008) traced norovirus strains in the environment and were able to identify outbreak strains in mussels exposed to sewage three months after the outbreak. Similarly, Ueki et al. (2005) were able to follow clinical strains from stool to sewage, to river waters and ultimately to oyster samples. Similar results were reported more than 25 years ago for a number of picornaviruses (enterovirus, poliovirus and hepatitis A virus) (Metcalf, 1982). A characteristic of these enteric viruses is their prolonged survival in the environment. Temperature appears to be the most important factor in virus survival, with low temperatures being associated with increases in virus persistence. Virus survival for many months has been observed at freezing or near-freezing temperatures (Gerba, 2007). UV light may damage the nucleic acid causing dimer formation. Double stranded DNA viruses like adenoviruses are more resistant to UV light inactivation than are enteroviruses (Gerba, 2007). In addition to these two principal environmental factors, other physical-chemical parameters such as $\mathrm{pH}$, salts, organic matter may impact virus survival and distribution, but generally this is only in a limited manner (Gerba, 2007). Few data are available on the behavior of norovirus since most studies have only reported qualitative virus detection. Realtime RT-PCR allows a quantification approach as does the use of cultivable animal norovirus strains as surrogates, and these approaches can be used to evaluate virus resistance to different environmental factors such as temperature or UV light (Duizer et al., 2004; Bae and Schwab, 2008).

\subsection{Persistance of viruses in shellfish tissues.}

It was generally thought that oysters act as mere filters or ionic traps, passively concentrating particles such as bacteria or virus. However, unlike enteric bacterial species, enteric viruses persist in shellfish for an extended period of time and it is this persistence that appears to result in its significant impact on public health. Viruses are principally concentrated in the pancreatic tissue, also called digestive diverticula. A number of different mechanisms have been suggested to explain differences between in virus accumulation between different oyster species, including mechanical entrapment and ionic bonding (di Girolamo et al., 1977; Metcalf, 1982; Schwab et al., 1998; Burkhardt and Calci, 2000). Virus accumulation in oysters can also depend on factors such as water temperature, mucus production, glycogen content of the connective tissue, and gonadal development. The importance of secreted acid mucopolysaccharides in the concentration of poliovirus was first demonstrated 30 years ago (di Girolamo et al., 1977). Mucus present on gills was also suspected to be important for concentration of reovirus by oysters (Bedford et al., 1978). Later hepatitis A virus was demonstrated to persist for several weeks after bio-accumulation, with infectious virus being detectable after three weeks and viral RNA still being detectable after six weeks using molecular assays (Kingsley and Richards, 2003). Infectious adenovirus was still detected in mussels for three weeks following bioaccumulation and in oysters for six weeks (Hernroth and Allard, 2007).

Virus-like particles (VLPs) have also been used to study virus persistence in shellfish. Loisy et al. (2005a) used rotavirus VLPs in oyster bioaccumulation studies, and viral particles persisted in oyster tissues for one to three months depending on the initial input concentrations (Loisy et al., 2005a). We used VLPs of the prototype genogroup I Norwalk 
virus (rNV VLP) and native Norwalk virus for bioaccumulation of oysters (Crassostrea gigas) to study norovirus persistence. We observed no differences in virus distribution between the native Norwalk virus and the VLPs, confirming that VLPs are good surrogates of infectious virions for this type of study. Interestingly, virus particle and VLP binding was to specific cell types, and some viral particles were detected in phagocytes located either in the epithelium or in the connective tissue (Le Guyader et al., 2006b). This observation might reflect the process of virus elimination or of normal digestion, but it is unclear if the immunoreactive material detected in phagocytes corresponds to particles being degraded and digested or whether particles are able to escape digestion. Specific binding was observed to the main ducts in the digestive tract and may be a mechanism for many viral particles to avoid entering in the food circulation and thus being degraded (Le Guyader et al., 2006b). The existence of a specific attachment to oyster cells and the internalization into phagocytes could explain the difficulty in using depuration to rid oysters of virus. In our work, we observed no differences in the tissue distribution of VLP binding between samples collected in March or October, although additional studies during other seasons are needed.

Human susceptibility to norovirus infection depends upon the presence or absence of certain carbohydrates of the $\mathrm{ABH}$, secretor and Lewis histo-blood group families (Tan and Jiang, 2007). Using tissues section of oyster bodies, we observed that recognition of oyster digestive epithelial cells by rNV VLPs also involves carbohydrates. Similar to what was observed with human histo-blood group structures, the use of human saliva to inhibit VLP attachment to oyster tissues or the use of mutant VLPs that abolish VLP binding to histoblood group antigens (alanine subtitution at positions H329A and W375A) prevent binding to oyster tissue. Additional studies showed that the oyster ligands are similar to histo-blood group A. Thus, NV binds to oyster tissues through an A-like carbohydrate structure, a binding site also used for attachment to carbohydrate on human epithelial cells (Tan and Jiang, 2007). Norovirus VLPs can also specifically bind to tissues of other oyster species (Crassostrea virginica, Crassostrea sikamea) or clams (Venerupis virginica) or mussels (Mytilis edulis)(Tian et al., 2007).

Distinct norovirus strains belonging to both genogroup I and II exhibit various binding patterns with different carbohydrate structures of the histo-blood group family, suggesting a possible coevolution of this group of viruses and their host or carrier vector. The importance of these observations and the interaction with specific carbohydrates in shellfish is of primary importance to protect the consumer, and more research needs to be conducted on this subject. For example it could be interesting to see if some bivalve mollusks less sensitive to contamination may be selected or if we can prevent the binding. The identification of the receptor may help to improve depuration.

\subsection{Depuration.}

Depuration processes are intended to eliminate or to purge live bivalves of the microbial contamination and is usually performed in tanks with clean sea-water. European legislation does not stipulate a minimum length of time over which depuration should be performed, but approximately two days is probably the most widely used depuration time in Europe (Richards 1988). Two days of depuration with clean sea-water will efficiently eliminate contaminating enteric bacteria, but as mentioned above, this is an insufficient length of time to efficiently remove enteric viral pathogens. Depurated shellfish have been implicated as the cause of a number of virus illness outbreaks (Gill et al., 1983; Heller et al., 1986; Le Guyader et al., 2006a, 2008).

Low levels of enterovirus contamination in soft shell clams following bioaccumulation were reported as often eliminated following depuration in early studies (Metcalf et al., 1979). Howeer, more recent data obtained using bioaccumulated shellfish have shown that although depuration may decrease virus concentration in shellfish tissues it has usually been insufficient to completely remove viruses (Abad et al., 1997; Schwab et al.,1998; Kingsley and 
Richards, 2003; Pommepuy et al., 2003; Loisy et al., 2005a). Different factors influence depuration efficiency. Increasing water temperatures can enhance virus removal, although an increase in depuration temperature may also result in increased shellfish mortality and induce some bacterial growth (Dore and Lees, 1995; Pommepuy et al., 2003). Poor depuration of enteric viruses can still occur at higher depuration temperatures as was reported in studies of Norwalk virus where only $7 \%$ of Norwalk virus was depurated compared to a $95 \%$ reduction in bacterial levels at a temperature of $22^{\circ} \mathrm{C}$ (Schwab et al., 1998). Feeding naturally contaminated oysters at $22^{\circ} \mathrm{C}$ increased depuration in a semi-professional size depuration tanks compared to fed oysters at lower temperatures (Pommepuy et al., 2003). The large tank allowed depuration of up to $900 \mathrm{~kg}$ of oysters and showed the feasibility of performing this procedure in the setting of a shellfish farm using producer conditions.

Phages have also been suggested as indicators of viral depuration as they are depurated less efficiently than E.coli (Doré et al., 2000). Feline calicivirus, another proposed surrogate, failed to be a good indicator of norovirus depuration from oysters (Ueki et al., 2007). Considering the differences in depuration observed among among various species of human enteric viruses (Abad et al., 1997) and differences in virus binding observed to shellfish tissues, extrapolating data from a phage to a human pathogen may be hazardous. The employment of appropriate surrogates remains a crucial issue in the evaluation of shellfish depuration.

\subsection{Other issues.}

Other approaches have been proposed to decrease the risk of shellfish for human consumption (Table 6). Cooking shellfish is one such approach, but failures of this strategy have also been reported. Following a large outbreak of viral gastroenteritis with cockles collected from the Thames estuary (England), a 'double cooking' was recommended (after an initial brief boil or steam treatment necessary for shell removal, cockle meats were to be boiled for a further $4 \mathrm{~min}$ ). However gastroenteritis and hepatitis A linked to cockle or mussel consumption were still reported (Millard et al. 1987). Frozen coquinas clams imported from Peru and served cooked in paella, were responsible for hundred of cases of hepatitis $A$ in Spain (Bosch et al. 2001). Croci et al. (2005) explored different approaches to kill the virus after bioaccumulation of hepatitis $A$ virus in mussels, and these investigators showed that extended cooking times were needed to completely inactivate the virus (Table 6). Failures of cooking may be due to the inability to attain sufficiently high temperatures to inactivate the virus or to the relative resistance of some enteric viruses to heat inactivation and their low infectious dose (Koff and Sear, 1967; McDonnell et al., 1997). In food, several factors may influence viral behavior (Le Guyader and Atmar, 2008).

High-hydrostatic pressure processing (HHP) has emerged as a promising technology for virus inactivation. HHP inactivates enteric viruses suspended in buffer but the inactivation rates are affected by treatment temperature and virus strain (Chen et al., 2005; Kingsley et al., 2007). It has been applied to shellfish that have bioaccumulated HAV or a murine norovirus, and greater than 1000 -fold reductions in viral titer was achieved with a treatment of $\leq 400$ Megapascal (MPa) for 5 min at $5^{\circ} \mathrm{C}$ (Calci et al., 2005; Kingsley et al., 2007). A potential disadvantage of this method is that changes in the character of the shellfish have been demonstrated in organoleptic studies, and some consumers prefer to eat live oysters (Cruz-Romero et al., 2004).

The effect of marination (immersion in an acetic acid-based mixture) has been evaluated in mussels contaminated with norovirus or HAV. The commercial marination process is a twostage procedure including a preliminary heat treatment (immersion in boiling water or steaming for $3 \mathrm{~min}$ ) and then marination for several weeks. After 4 weeks of marination, the infectious titer for HAV decreased approximately 50-fold, and human norovirus RNA was still detected by real-time RT-PCR (Hewitt and Greening, 2004). These data suggest that marination alone is not sufficient to inactivate enteric viral pathogens in shellfish. 


\section{Perspectives}

Although seafood can generally be regarded as a wholesome, safe, and nutritious food, it may occasionally pose consumer risks. Regulations are currently based on routinely monitoring shellfish for fecal bacteria to determine their sanitary quality. However, viral contamination of bivalve molluscs is currently recognised as one of the major causes of illness associated with seafood. Monitoring viral contamination is complex and must take into account different factors such as detection methods, technology, social demands and the sustainable development of aquaculture. Recent advances in technology, especially in developing molecular tools, make it possible to look for pathogens directly in shellfish implicated in outbreaks. Evaluation of seafood for the presence of norovirus and hepatitis $A$ virus for regulatory purposes has been recommended by experts involved in EU, FAO and WHO working groups. Mandatory surveillance for virus may be implemented in the near future but additional information including level of exposure and virus infectious dose are still needed to assess risks.

Different actions may be considered to lower the contamination of shellfish bed in coastal area:

Reduction of fecal input in coastal areas. Water quality studies have demonstrated the feasibility of determining the main sources of fecal contamination and to identify the critical points in the catchments. Hydrodynamical models when applied to these contaminants, even if they need further development and have to be validated by data bases, could lead to rational bases for the choice of treatment levels based on results from screening purposes to limit the contamination.

Implementation of warning systems: in developed countries, some data are already available on outbreaks occurring in the population, so, associated with forecast information, salinity, STP failure and other, a warning system could lead to real-time assessments of water quality in bathing or harvesting areas. The development of new tools for rapid pathogen detection (for example micro-array) may help to collect additional information on the presence of pathogens in sewage or waters.

To limit shellfish contamination, the most desirable and effective option is to reduce the viral input. Villages, small towns and dwellings must be equipped with small individual treatment tanks to comply with the regulations. New technologies may be needed to improve removal of viruses from sewage effluents (Shannon et al., 2008). Another solution could be the relocation of shellfish aquaculture away from the contamination sources.

Other factors will also need to be considered to protect the consumer and to provide safe shellfish on the market. An important aspect of monitoring concerns the sustainable development of aquaculture. This development is closely linked to environmental quality in shellfish breeding areas. The nested-regulations set up for water quality, bathing areas and shellfish growing areas, if well applied, should provide the guarantees and the management tools. There are promising examples of coastal management designed to reduce the fecal load which could make recovery of water quality feasible. Used in association with early warning systems, they could help ensure shellfish quality and increase consumer confidence and thus, would greatly contribute to sustainable development of aquaculture. Shellfish have long been recognized as being beneficial to human health and this benefit should also be taken into consideration in managing the coastal areas and preserving the water quality.

\section{References}

Abad F X, Pinto R M, Diez J M, and Bosch A (1994) Disinfection of human enteric viruses in water by copper and silver in combination with low levels of chlorine, Appl Environ Microbiol, $60,2377-2383$. 
Abad F X, Pinto R M, Gajardo R, and Bosch A (1997), Viruses in mussels: public health implications and depuration, J Food Prot 60, 677-681.

Aggarwal R, and Naik S (2008) Enterically transmitted hepatitis. In: Food-borne viruses progress and challenges, Koopmans M, Cliver D O, Bosch A (Eds) p65-85

Anderson E J, and Weber S G (2004), Rotavirus infection in adults, Lancet Inf Dis 4, 91-99.

Arnal C, Crance J M., Gantzer C, Schwartzbrod L, Deloince R, and Billaudel S (1998), Persistence of infectious hepatitis A virus and its genome in artificial sweater, Zentralbl Hyg Umweltmed, 201, 279-284.

Atmar R L, Metcalf T G, Neill F H, and Estes M K (1993), Detection of enteric viruses in oysters by using the polymerase chain reaction, Appl Environ Microbiol, 59, 631-635.

Atmar R L, Neill F H, Romalde J L, Le Guyader F, Woodley C M, Metcalf T G, and Estes M K (1995), Detection of Norwalk virus and Hepatitis A virus in shellfish tissues with the PCR, Appl Environ Microbiol, 61, 3014-3018.

Atmar R L, and Estes M K (2006), The epidemiologic and clinical importance of norovirus infection, Gastroenterol Clin N Am, 35, 275-290.

Atmar R L, Opekun A R, Gilger M A, Estes M K, Crawford S E, Neill F H, Graham D Y (2008), Duration and magnitude of Norwalk virus shedding following experimental human infection, Emerg Inf Dis, 14, 1553-1557.

Bae J, and Schwab K J (2008), Evaluation of murine norovirus, feline calicivirus, poliovirus, and MS2 surrogates for human norovirus in a model of viral persistence in surface water and groundwater, Appl Environ Microbiol, 74, 477-484.

Bedford A J, Williams G, and Bellamy A R (1978), Virus accumulation by the rock oyster crassostrea glomerata, Appl Environ Microbiol, 35, 1012-1018.

Blanton L H, Adams S M, Beard R S, Wei G, Bulens S N, Widdowson M-A, Glass R I and Monroe S S (2006), Molecular and epidemiologic trends of caliciviruses associated with outbreaks of acute gastroenteritis in the United States, 2000-2004, J Inf Dis, 193, 413-421.

Bosch A, Sánchez G, Le Guyader F, Vanaclocha H, Haugarreau L, and Pintó R M (2001), Human enteric viruses in coquina clams associated with a large hepatitis A outbreak, Wat Sci Tech, 43, 61-66.

Boxman I L A, Tilburg J J H C, te Loeke N A J M, Vennema, Jonker K, de Boer E, and Koopmans M (2006), Detection of noroviruses in shellfish in the Netherlands, Int J Food Microbiol, 108, 391-396.

Brooks H A, Gersberg R M, and Dhar A K (2005), Detection and quantification of hepatitis A virus in seawater via real-time RT-PCR, J Virol Meth, 127, 109-118.

Bull R A, Tanaka M M, and White P A (2007), Norovirus recombination, J Gen Virol, 88, 3347-3359.

Burkhardt W, and Calci K R (2000), Selective accumulation may account for shellfishassociated viral illness, Appl Environ Microbiol, 66,1375-1378.

Butt A A, Aldridge K E, and Sanders C V (2004), Infections related to the ingestion of seafood. Part I: viral and bacterial infections, Lancet Inf Dis, 4, 201-212.

Cacopardo B, Russo R, Preiser W, Benanti F, Brancati G and Nunnari A (1997), Acute hepatitis E in Catania (Eastern Sicily) 1980-1994. The role of hepatitis E, Infection, 25, 313316.

Calci K R, Meade G K, Tezloff R C, and Kinsgley D H (2005), High-pressure inactivation of hepatitis A virus within oysters, Appl Environ Microbiol, 71, 339-343.

CDC (2006), Prevention of hepatitis A through active or passive immunization, $M M W R, 55$ (RR7), 1-23.

Chan M C W, Sung J J Y, Lam R K Y, Chan P K S, Lee N L S, Lai R W M, and Leung W K (2006), Fecal viral load and norovirus associated gastroenteritis, Emerg Inf Dis, 12, 12781280.

Cheetham S, Souza M, Meulia T, Grimes S, Han M G, and Saif L J (2006), Pathogenesis of a genogroup II human norovirus in gnotobiotic pigs, J Virol, 80,10372-10381. 
Chen H, Hoover D G, and Kinsgley D H (2005), Temperature and treatment time influence high hydrostatic pressure inactivation of feline calicivirus, a norovirus surrogate, J Food Prot, 68, 2389-2394.

Costafreda M I, Bosch A, and Pinto R M (2006), Development, evaluation, and standardization of a real-time TaqMan reverse transcription-PCR assay for quantification of hepatitis A virus in clinical and shellfish samples, Appl Environ Microbiol, 72, 3846-3855.

Costantini V, Loisy F, Joens L, Le Guyader F S, and Saif L J (2006), Human and animal enteric caliciviruses in oysters from different coastal regions of the United States, Appl Environ Microbiol, 72, 1800-1809.

Croci L, De Medici D, Scalfaro C, Fiore A, Divizia M, Donia D, Cosentino A M, Moretti P, and Costanti G (2000), Determination of enteroviruses, hepatitis A virus, bacteriophages and Escherichia coli in Adriatic sea mussels, J Appl Microbiol, 88, 293-298.

Croci L, De Medici D, Di Pasquale S, and Toti L (2005), Resistance of hepatitis A virus in mussels subjected to different domestic cooking, Int J Food Microbiol, 105, 139-144.

Cruz-Romero M, Smiddy M, Hill C, Kerry J P, and Kelly A L (2004), Effects of high pressure treatment on physicochemical characteristics of fresh oysters (Crassostrea gigas), Innov Food Sci Emerg Tech, 5, 161-169.

Da Silva A, Le Saux J-C, Parnaudeau S, Pommepuy M, Elimelech M, and Le Guyader F S (2007), Evaluation of removal of noroviruses during wastewater treatment, using real-time reverse transcription-PCR: different behaviors of genogroups I and II, Appl Environ Microbiol, 73, 7891-7897

De Roda-Husman A-M, Lodder-Verschoor F, van der berg H H L J, Le Guyader F S, van Pelt $H$, van der Poel W H M, and Rutjes S A (2007), Rapid virus detection procedures for molecular tracing of shellfish associated with disease outbreaks, J Food Prot, 70; 967-974.

Dhama K, Chauban R S, Mahendran M, and Malik S V S (2008), Rotavirus diarrhea in bovines and other domestic animals, Vet Res Commun, On line first

Di Girolamo R, Liston J, and Matches J (1970), Survival of virus in chilled, frozen, and processed oysters, Appl Environ, Microbiol, 20, 58-63.

Di Girolamo R, Liston J, and Matches J (1977), lonic binding, the mechanism of viral uptake by shellfish mucus, Appl Environ Microbiol, 33, 19-25.

Dore W J, and Lees D N (1995), Behavior of Escherichia coli and male-specific bacteriophage in environmentally contaminated bivalve molluscs before and after depuration, Appl Environ Microbiol, 61, 2830-2834.

Doré W, Henshilwood K, and Lees D N (2000), Evaluation of F-specific RNA bacteriophage as a candidate human enteric virus indicator for bivalves molluscan shellfish, Appl Environ Microbiol, 66, 1280-1285.

Dowell S F (2001), Seasonal variation in host susceptibility and cycles of certain infectious diseases, Emerg Inf Dis, 7, 369-374.

Dubois E, Merle G, Roquier C, Trompette A, Le Guyader F, Cruciere C, and Chomel J-J. (2004), Diversity of enterovirus sequences detected in oysters by RT-heminested PCR, Int J Food Microbiol, 92, 35-43.

Duizer E, Bijkerk P, Rockx B, de Groot A, Twisk F, and Koopmans M (2004), Inactivation of caliciviruses, Appl Environ Microbiol, 70, 4538-4545.

El Senousy W M, Guix S, Abid I, Pinto R M and Bosch A (2007), Removal of astrovirus from water and sewage treatment plants, evaluated by a competitive reverse transcription-PCR, Appl Environ Microbiol, 73, 164-167.

Estes M K and Kapikian A Z (2007), Rotaviruses, in: Fields Virology, Knipe D M, Howley P M, (Eds), Baltimore, pp 1917-1974.

Fong T-T and Lipp E K (2005), Enteric viruses of humans and animal in aquatic environments: health risks, detection and potential water quality assessment tools, Microbiol Mol Biol Rev, 69, 357-371.

Formiga-Cruz M, Allard A K, Conden Hansson A C, Henshilwood K, Hernroth B E, Joffre J, Lees D N, Lucea F, Papapetropoulou M, Rangdale R E, Tsibouxi A, Vantarakis A and Girones R (2003), Evaluation of potential indicators of viral contamination in shellfish and their applicability to diverse geographical areas, Appl Environ Microbiol, 69, 1556-1563. 
Freeman M M, Kerin T, Hull J, McCaustland K, and Gentsch J (2008), Enhancement of detection and quantification of rotavirus in stool using a modified real-time RT-PCR assay, $J$ Med Virol, 80, 1489-1496.

Fukuda S, Sasaki Y, and Seo M (2008), Rapid and sensitive detection of norovirus genomes in oysters by a two step isothermal amplification assay system combining nucleic acid sequence based amplification and reverse transcription-loop-mediated isothermal amplification assays, Appl Environ Microbiol, 74, 3912-3914.

Gabbay Y B, Borges A A, Oliveira D S, Linhares A C, Mascarenhas J D, Barardi C R, Simões C M, Wang Y, Glass R I, and Jiang B (2008), Evidence for zoonotic transmission of group $C$ rotaviruses among children in Belém, Brazil, J Med Virol, 80, 1666-1674.

Garcia C, DuPont H L, Long K Z, Santos J X, and Ko G P (2006), Asymptomatic norovirus infection in Mexican children, J Clin Microbiol , 44, 2997-3000.

Gerba C P (2007), Virus occurrence and survival in the environmental waters, in Human viruses in water, Bosch $A(E d)$ Perspective in Medical virology (Zuckerman $A \mathrm{~J}$, and Mushahwar I K (eds), pp 91-108.

Gill O N, Cubitt W D, Wiggan D A, Watney B M, and Bartlett C L R (1983), Epidemic of gastroenteritis caused by oysters contaminated with small round structured viruses, $\mathrm{Br} M e d$ $\mathrm{J}, 287,1532-1534$.

Griffin D W, Donaldson K A, Paul J H, and Rose J B (2003), Pathogenic human viruses in coastal waters, Clin Microbiol Rev, 16, 129-143.

Halliday M L, Kang LY, Zhou T R, Hu M D, Pan Q C, Fu T Y, Huang Y S, and Hu S L (1991), An epidemic of hepatitis $A$ attributable to the ingestion of raw clams in Shangai, China, $J$ Inf Dis, 164, 852-859.

Haramoto E, Katayama H, Oguma K, and Oghaki S (2005), Application of cation-coated filter method to detection of noroviruses, enteroviruses, adenoviruses, and torque teno viruses in the Tamagawa river in Japan, Appl Environ Microbiol, 71, 2403-2411.

Haramoto E, Katayama H, Oguma K, Yamashita H, Tajima A, Nakajima H, and Ohgaki S (2006), Seasonal profiles of human noroviruses and indicator bacteria in a wastewater treatment plant in Tokyo, Japan, Wat Sci Tech, 54, 301-308.

Haramoto E, Katayama H, Phanuwan C, and Oghaki S (2008), Quantitative detection of sapoviruses in wastewater and river water in Japan, Let Appl Microbiol, 46, 408-413.

Havelaar A H (1993), Bacteriophages as models of human enteric viruses in the environment, ASM News, 59, 614-619.

Heller D, Gill O N, Raynham E, Kirkland T, Zadick P M, and Stanwell-Smith R (1986), An outbreak of gastrointestinal illness associated with consumption of raw depurated oysters, Brit Med J, 292, 1726-1727.

Hernroth B E, Conden-Hansson A-C, Rehnstam-Holm A-S, Girones R, and Allard A K (2002), Environmental factors influencing human viral pathogens and their potential indicator organisms in the blue mussel, Mytilus edulis: the first scandinavian report, Appl Environ Microbiol, 68, 4523-4533.

Hernroth B E, and Allard A K (2007), The persistence of infectious adenovirus (type 35) in mussels (Mytilus edulis) and oysters (ostrea edulis), Int J Food Microbiol, 113, 296-302.

Hewitt J and Greening G E (2004), Survival and persistence of norovirus, hepatitis A virus, and feline calicivirus in marinated mussels, J Food Prot, 67, 1743-1750.

Hewitt J, and Greening G E (2006), Effect of heat treatment on hepatitis A virus and norovirus in New zealand Greenshellf mussels (Perna canaliculus) by quantitative real-time reverse transcription PCR and cell culture, J Food Prot, 69, 2217-2223.

Hijnen W A W, Beerendonk E F, Medema G J (2006), Inactivation credit of UV radiation for virus, bacteria and protozoan (oo)cysts in water: a review, Water Res, 40, 3-22.

Hollinger F B and Emerson S U (2007), Hepatitis A virus, in: Fields Virology, Knipe D M, Howley P M, (Eds), Baltimore, pp 911-947.

Hovi T (2006), Surveillance for polioviruses, Biologicals, 34, 123-126.

Jothikumar N, Lowther J A, Henshilwwod K, Lees D N, Hill V R, and Vinje J (2005), Rapid and sensitive detection of noroviruses by using TaqMan based one-step reverse 
transcription-PCR assays and application to naturally contaminated shellfish samples, Appl Environ Microbiol, 71, 1870-1875.

Kaci S, Nockler K, and Johne R (2008), Detection of hepatitis E in archived german wild boar serum samples, Vet Microbiol, 128, 380-385.

Kageyama T, Kojima S, Shinohara M, Uchida K, Fukushi S, Hoshino F B, Takeda N, and Katayama K (2003), Broadly reactive and highly sensitive assay for Norwalk-like viruses based on real-time quantitative reverse transcription-PCR, J Clin Microbiol 41, 154-157.

Kaplan J E, Feldman R, Campbell D S, Lookabaugh C, ad Gary G W (1982), The frequency of a Norwalk-like pattern of illness in outbreaks of acute gastroenteritis, Am J Public Health, 72, 1329-1332.

Katayama H, Haramoto E, Oguma K, Yamashita H, Tajima A, Nakajima H, Ohgaki S (2008), One-year monthly quantitative survey of noroviruses, enteroviruses and adenoviruses in wastewater collected from six plants in Japan, Wat Res, 42, 1441-1448

Kato T, Tohma H, Miki O, Shibata T, Tamura M (2005), Degradation of norovirus in sewage treatment water by photocatalytic ultraviolet disinfection, Nippon Steel Tech Rep, 92, 40-44.

Kingsley D H, and Richards G P (2003) Persistence of hepatitis A virus in oysters, J Food Prot, 66, 331-334.

Kingsley D H (2007), An RNA extraction protocol for shellfish-borne viruses, $J$ Virol Meth 141, 58-62.

Kingsley D H, Holliman D R, Calci K R, Chen H, and Flick G J (2007), Inactivation of a norovirus by high pressure processing, Appl Environ Microbiol, 73, 581-585.

Kittigul L, Pombubpa K, Rattanatham T, Diraphat $P$, Utrarachkij F, Pungchitton S, Khamrin $P$, and Ushijima H, (2008), Development of a method for concentrating and detecting rotavirus in oysters, Int J Food Microbiol, 122, 204-210.

Koff R S and Sear H S (1967), Internal temperature of steamed clams, N Engl J Med, 276, 737-739.

Kohn M A, Farley T A, Ando T, Curtis M, Willson S A, Monroe S S, Baron R C, Macfarland L $M$, and Glass R I (1995), An outbreak of Norwalk virus gastroenteritis associated with eating raw oysters, JAMA, 273, 466-471.

Koizumi Y, Isoda N, Sato Y, Iwaki T, Ono K, Ido K, Sugano K, Takahashi M, Nishoizawa T, and Okamoto $\mathrm{H}$ (2004), Infection of a japanese patient by genotype 4 hepatitis $E$ virus while traveling in Vietnam, J Clin Microbiol, 42, 3883-3885.

La Rosa G, Fontana S, Di Grazia A, laconelli M, Pourshaban m, and Muscillo M (2007), Molecular identification and genetic analysis of noroviruses genogroups I and II in water environment: comparative analysis of different RT-PCR assays, Appl Environ Microbiol, 73, 4152-4161.

Laverick M A, Wyn-Jones A P, and Carter M J (2004), Quantitative RT-PCR for the enumeration of noroviruses (Norwalk-like viruses) in water and sewage, Lett Appl Microbiol, 39, 127-136.

Lee T, Yam W C, Tam T Y, Ho B S W, Ng M H, and Broom M J (1999), Occurence of hepatitis $A$ virus in green-lipped mussels (perna viridis), Wat Res, 33, 885-889.

Lee N, Chan M C W, Wong B, Choi K W, Sin W, Lui G, Chan P K S, Lai R W M, Cockram C S, Sung J J Y, and Leung W K (2007), Fecal viral concentration and diarrhea in norovirus gastroenteritis, Emerg Infect Dis, 13, 1399-1401.

Lee J E, Zoh K D, and Ko G P (2008), Inactivation and UV disinfection of murine norovirus with $\mathrm{TiO}_{2}$ under various environmental conditions, Appl Environ Microbiol, 74, 2111-2117.

Le Cann P, Ranarijaona S, Monpoeho S, Le Guyader F S, and Ferré V (2004), Quantification of human astroviruses in sewage using real-time RT-PCR, Res Microbiol, 155, 11-15.

Le Guyader F, Haugarreau L, Miossec L, Dubois E, and Pommepuy M (2000), Three-year study to assess human enteric viruses in shellfish, Appl Environ Microbiol, 66, 3241-3248.

Le Guyader F S, Neill F H, Dubois E, Bon F, Loisy F, Kohli E, Pommepuy M, and Atmar R L (2003), A semi-quantitative approach to estimate Norwalk-like virus contamination of oysters implicated in an outbreak, Int J Food Microbiol, 87, 107-112.

Le Guyader F S, Bon F, DeMedici D, Parnaudeau S, Bertome A, Crudeli S, Doyle A, Zidane M, Suffredini E, Kohli E, Maddalo F, Monini M, Gallay A, Pommepuy M, Pothier P, and 
Ruggeri F M (2006a), Detection of noroviruses in an international gastroenteritis outbreak linked to oyster consumption, J Clin Microbiol, 44, 3878-3882.

Le Guyader F S, Loisy F, Atmar R L, Hutson A M, Estes M K, Ruvoen-Clouet N, Pommepuy $\mathrm{M}$, and Le Pendu J (2006b), Norwalk virus specific binding to oyster digestive tissues, Emerg Inf Dis, 12, 931-936.

Le Guyader F S and Atmar R L (2007), Viruses in shellfish, in : Human viruses in water, Bosch A (Ed) Perspective in Medical Virology, Zuckerman A J, and Mushahwar I K (eds), pp 205-226.

Le Guyader F S and Atmar R L (2008), Binding and inactivation of viruses on and in food, with a focus on the role of the matrix, in Food-borne viruses, progress and challenges, Koopmans M P G, Cleaver D O, and Bosch A (Eds) Emerging issues in food safety, Doule M $P$ and Erickson M C (eds), pp 189-208.

Le Guyader F S, Le Saux J-C, Ambert-Balay K, Krol J, Serais O, Parnaudeau S, Giraudon H, Delmas G, Pommepuy M, Pothier P, and Atmar R L (2008), A french oyster-reated gastroenteritis outbreak: Aichi virus,norovirus, astrovirus, enterovirus and rotavirus all involved in clinical cases, J Clin Microbiol doi:10.1128/JCM.01044-08.

Le Guyader F S, Parnaudeau S, Schaeffer J, Bosch A, Loisy F, Pommepuy M, and Atmar R L, Norovirus detection in shellfish and approach to quantification, submitted to Appl Environ Microbiol

Lewis H C, Boisson S, ljaz S, Hewitt K, Ngui S L, Boxall E, Teo C G, and Morgan D (2008), Hepatitis E in England and Wales, Emerg Inf Dis, 14, 165-167.

Lipp E K, Jarrell J L, Griffin D W, Lukasik J, Jacukiewicz J, and Rose J B (2002), Preliminary evidence for human fecal contamination in corals of the florida keys, USA, Mar Poll Bull, 44, 666-670.

Lodder W J, and de Roda- Husman A M (2005), Presence of noroviruses and other enteric viruses in sewage and surface waters in The Netherlands, Appl Environ Microbiol, 71, 14531461.

Lodder-Verschoor F, de Roda- Husman A M, van der Berg H H J L, Stein A, van peltHeerschap H M L, and van der Poel W H M (2005), Year round screening of noncommercial and commercial oysters for the presence of human pathogenic viruses, J Food Prot, 68, 1853-1859.

Loisy F, Atmar R L, Le Saux J-C, Cohen J, Caprais M-P, Pommepuy M, and Le Guyader F S (2005a), Rotavirus virus like particles as surrogates to evaluate virus persistence in shellfish, Appl Environ Microbiol, 71, 6049-53.

Loisy F, Atmar R L, Guillon P, Le Cann P, Pommepuy M, and Le Guyader S F (2005b), Realtime RT-PCR for norovirus screening in shellfish, $J$ Virol Meth, 123, 1-7.

Lopman B, Vennema H, Kohli E, Pothier P, Sanchez A, Negredo A, Buesa J, Schreier E, Reacher M, Brown D, Gray J, Iturriza M, Gallimore C, Bottiger B, Hedlund K O, Torven M, von Bonsdorff C-H, Maunula L, Poljsak-Prijatelj M, Zimsek J, Reuter G, Szucs G, Melegh B, Svennson L, van Duijnhoven Y, and Koopmans M (2004), Increase in viral gastroenteritis outbreaks in Europe and epidemic spread of new norovirus variant, Lancet, 363: 682-688.

Lopman B, Zambon M, and Brown D W (2008), The evolution of norovirus, the gastric flu, PlosMedicine, 5,1-3.

Lowther J, Henshilwood K and Lees D L (2008), Determination of norovirus contamination in oysters from two commercial harvesting areas over an extended period, using semiquantitative real-time reverse trancription PCR, J Food Prot, 71, 1427-1433.

Lu L, Li C, and Hagedorn C H (2006), Phylogenetic analysis of global hepatitis E virus sequences: genetic diversity, subtypes and zoonosis, Rev Med Virol, 16, 5-36.

Ludwig A, Adams O, Laws H J, Schroten H, and Tenenbaum T (2008), Quantitative detection of norovirus excretion in pediatric patients with cancer and prolonged gastroenteritis and shedding of norovirus, J Med Virol, 80, 1461-1467.

Mackowiak P A, Caraway C T, Portnoy B L (1976), Oyster-associated hepatitis: lessons from the Louisiana experience, Am J Epidemiol, 103, 181-191. 
Martella V, Colombrita D, Lorusso E, Draghin E, Fiorentini S, De Grazia S, Bányai K, Ciarlet M, Caruso A, and Buonavoglia C (2008), Detection of a porcine-like rotavirus in a child with enteritis in Italy, J Clin Microbiol, 46, 3501-3507.

Mattison K, Shukla A, Cook A, Pollari F, Friendship R, Kelton D, Bidawid S, and Farber J M (2007), Human noroviruses in swine and cattle, Emerg Inf Dis, 13, 1184-1188

McDonnell S, Kirkland K B, Hlady W G, Aristeguieta C, Hopkins R S, Monroe S S, and Glass R I (1997), Failure of cooking to prevent shellfish-associated viral gastroenteritis, Arch Intern Med, 157, 111-116.

Mead P S, Slutsker L, Dietz V, MacCaig L F, Bresee J S, Shapiro C, Griffin P M, and Tauxe R V (1999), Food-related illness and death in the United States, Emerg Inf Dis, 5, 607-625.

Mendez E and Arias C F (2007), Astroviruses, in: Fields Virology, Knipe D M, Howley P M, (Eds), Baltimore, pp 1023-1067.

Metcalf T G, Mullin B, Eckerson D, Moulton E, and Larkin E P (1979), Bioaccumulation and depuration of enteroviruses by the soft-shelled clam, mya arenaria, Appl Environ Microbiol, $38,275-282$.

Metcalf T G, Moulton E, and Eckerson D (1980), Improved method and test strategy for recovery of enteric viruses from shellfish, Appl Environ Microbiol 39, 141-152.

Metcalf T G (1982), Viruses in shellfish growing waters, Environ Internat 7, 21-27.

Miagostovich M P, Ferreira F F M, Guimaraes F R, Fumian T M, Dniz-Mendes L, Luz S L B, Silva L A, and Leite J P G (2008), Molecular detection and characterization of gastroenteritis viruses occuring naturally in the stream waters of Manaus, central amazonia, Brazil, Appl Environ Microbiol, 74, 375-382.

Millard J, Appleton H, and Parry J V (1987), Studies on heat inactivation of hepatitis A virus with special reference to shellfish, Epidem Infect, 98, 397-414.

Milne S A, Gallacher S, Cash P, Lees D N, Henshilwood K, and Porter A J R (2007), A sensitive and reliable reverse transcriptase PCR-Enzyme-linked immunosorbent assay for the detection of human parthogenic viruses in bivalve mollusks, J Food Prot, 70, 1475-1482.

Miossec L, Le Guyader F S, Pelletier D, Haugarreau L, Caprais M-P, and Pommepuy M (2001), Validity of Escherichia coli, enterovirus and F-specific RNA bacteriophages as indicators of viral shellfish contamination, J Shellfish Res, 20, 1223-1227.

Mounts A W, Ando T, Koopmans M, Bresee J S, Noel J, and Glass R I (2000), Cold weather seasonality of gastroenteritis associated with Norwalk-like viruses, $J$ Infect Dis, 181, S284S287.

Morse D L, Guzewich J J, Hanrahan J P, Stricof R, Shayegani M, Deibel R, Grabau J C, Nowak N A, Herrmann J E, Cukor G, and Blacklow N R (1986), Widespread outbreaks of clam- and oyster-associated gastroenteritis: role of Norwalk virus, New Engl J Med, 314, 678-681.

Munian-Mujika I, Calvo M, Lucena F, and Girones R (2003), Comparative analysis of viral pathogens and potential indicators in shellfish, Int J Food Microbiol, 83, 75-85.

Murphy A M, Grohmann G S, Christopher R J, Lopez W A, Davey G R, and Millsom R H, (1979), An Australia-wide outbreak of gastroenteritis from oysters caused by Norwalk virus, Med J Australia, 2, 329-333.

Myrmel M, Berg E M M, Rimstad E, and Grinde B (2004), Detection of enteric viruses in shellfish from the Norwegian coast, Appl Environ Microbiol, 70, 2678-2684.

Myrmel M, Berg E M M, Grinde B, and Rimstad E (2006), Enteric viruses in inlet and outlet samples from sewage treatment plants, $J$ Wat Health, 4, 197-209.

Nenonen N P, Hannoun C, Horl P, Hernroth B, and Bergstrom T (2008), Tracing of norovirus outbreaks strains in mussels collected near sewage effluents, Appl Environ Microbiol, 74, 2544-2549.

Nishida T, Kimura H, Saitoh M, Shinohora M, Kato M, Fukuda S, Munemura T, Mikami T, Kawamoto T, Akiyama M, Kato Y, Nishi K, Kozawa K, and Nishio O (2003), Detection, quantitation, and phylogenetic analysis of noroviruses in japanese oysters, Appl Environ Microbiol, 69, 5782-5786. 
Nishida T, Nishio O, Kato M, Chuma T, Kato H, Iwata H, and Kimura H (2007), Genotyping and quantitation of norovirus in oyters from two distinct sea areas in japan, Microbiol Immunol, 51, 177-184.

Oh D-Y, Gaedicke G, and Schreir J M (2003), Viral agents of acute gastroenteritis in German children: Prevalence and molecular diversity, J Med Virol, 71, 82-93.

Oka T, Katayama K, Hansman G S, Kageyama T, Ogawa S, Wu F-T, Takeda N (2006) Detection of human sapovirus by real-time reverse transcription polymerase chain reaction, $\mathrm{J}$ Med Virol 78, 1347-1353.

Oliver S L, Dastjerdi A M, Wong S, El-Attae L, Gallimore C, Brown D W G, Green J, and Bridger J C (2003), Molecular characterization of bovine enteric caliciviruses : a distinct third genogroup of noroviruses (Norwalk-like viruses) unlikely to be risk to humans, $\mathrm{J}$ Virol, 77, 2789-2798.

Ottoson J., Hansen A, Westrell T, Johansen K, Norder H, and Stenstrom T A (2006), removal of noro- and enteroviruses, giardia cysts, cryptosporidium oocysts, and fecal indicators at four secondary wastewater treatment plants in Sweden, Wat Environ Res, 78, 828-834.

Pallansch M and Roos R (2007), Enteroviruses: polioviruses, coxsackieviruses, echoviruses, and newer enteroviruses, in: Fields Virology, Knipe D M, Howley P M, (Eds), Baltimore, pp 839-893.

Parashar U D, Holman R C, Clarke M J, Bresee J S, and Glass R I (1998), Hospitalizations associated with rotavirus diarrhea in the United States, 1993 through 1995: surveillance based on the new ICD-9-CM rotavirus-specific diagnostic code, J Infec Dis, 177, 13-17.

Park S-I, Jeong C, Park S-J, Kim H-H, Jeong Y-J, Hyun B-H, Chun Y-H, Kang M-I, Cho K-O (2008), Molecular detection and characterization of unclassified bovine enteric caliciviruses in South Korea, Vet Microbiol, 130, 371-379.

Patel M N, Widdowson M-A, Glass R I, Akazawa K, Vnje J, and Parashar U D (2008), Systematic literature review of role of noroviruses in sporadic gastroenteritis, Emerg Inf Dis, 14, 1224-1231.

Pinto R M, and Bosch A (2008), Rethinking virus detection in food, In: Food-borne viruses progress and challenges, Koopmans $M$, Cliver D O, Bosch A (Eds) p 171-188

Pinto R M, and Saiz J-C (2007), Enteric hepatitis viruses, in: Human viruses in water, Bosch A (Ed) Perspective in Medical Virology, Zuckerman A J, and Mushahwar I K (eds), pp 39-68. Pommepuy M, Caprais M-P, Le Saux J-C, Le Mennec C, Parnaudeau S, Madec Y, Monnier M, Brest G, and Le Guyader F S (2003), Evaluation of viral shellfish depuration in a semiprofessional size tank, $\mathrm{p}$ 485-499. In: Molluscan Shellfish Safety, Villalba A, Reguera B, Romalde J L, Beiras R, (ed.), Conseilleria de Pesca e Assuntos maritimos da Xunta de Galicia and Intergovernmental Oceanographic Commission of UNESCO, Santiago de Compostela (Spain).

Pommepuy M, Dumas F, Caprais M P, Camus P, Le Mennec C, Parnaudeau S, Haugarreau L, Sarrette B, Vilagines P, Pothier P, Kholi E and Le Guyader F S (2004), Sewage impact on shellfish microbial contamination, Wat Sci Tech, 50, 117-124.

Pommepuy M, Hervio-Heath D, Caprais M-P, Gourmelon M, and Le Guyader F S (2005), Fecal contamination in coastal area: an engineering approach. In: Oceans and Health: Pathogens in the marine environment, Belkin S (Eds) Kluwer academic/Plenum Publishers, USA, pp. 331-360.

Pusch D, Oh D Y, Wolf S, Dumke R, Schroter-Bobsin U, Hohne M, Roske I, and Schreier E (2005), Detection of enteric viruses and bacterial indicators in German environmental waters. Arch Virol, 150, 929-947.

Renou C, Cadranel J-F, Bourlière $M$, Halfon $P$, Ouzan $D$, Rifflet $H$, Carenco $P$, Harafa $A$, Bertrand J J, Boutrouille A, Muller P, Igual J-P, Decoppet A, Eloit M, and Pavio N (2007), Possible zoonotic transmission of Hepatitis $\mathrm{E}$ from pet pig to its owner, Emerg Inf Dis, 13,1094-1096.

Reuter G, Biro H, and Szucs G (2006), Enteric caliciviruses in domestic pigs in Hungary, Arch Virol, 132, 611-614.

Richards G P (1985), Outbreaks of shellfish-associated enteric virus illness in the United States : requisite for development of viral guidelines, J Food Prot, 48, 815-823. 
Richards G P (1987), Shellfish associated enteric virus illness in the United states, 19341984, Estuaries, 10, 84-85.

Richards G P (1988), Microbial purification of shellfish: a review of depuration and relaying, $J$ Food Prot, 51, 218-251.

Richards G P (1999), Limitations of molecular biological techniques for assessing the virological safety of foods, J Food Prot, 62, 691-697.

Riou P, Le Saux J-C, Dumas F, Caprais M-P, Le Guyader F S, and Pommepuy M (2007), Microbial impact of small tributaries on water and shellfish quality in shallow coastal areas, Wat Res, 41, 2774-2786.

Rippey S R (1994), Infectious diseases associated with molluscan shellfish consumption, Clin Microbiol Rev, 7, 419-425.

Rohayem J, Dumke R, Jaeger K, Schroter-Bobsin U, Mogel M, Kruse A, Jacobs E, and Rethwilm A (2006), Assessing the risk of transmission of viral diseases in flooded areas: viral load of the river Elbe in Dresden during the flood of August 2002, Intervirology, 49, 370-376.

Romalde J L, Estes M K, Szucs G, Atmar R L, Woodley C M, and Metcalf T G (1994), In situ detection of hepatitis A virus in cell cultures and shellfish tissues, Appl Environ Microbiol, 60, 1921-1926.

Rose M A, Dhar A K, Brooks H A, Zecchini F, and Gersberg R M (2006), Quantitation of hepatitis $A$ virus and enterovirus levels in the lagoon canals and Lido beach of Venice, Italy, using real-time RT-PCR, Wat Res, 40, 2387-2396.

Rutjes S A, Lodder W J, Bouwknegt M, and de Roda-Husman A-M (2007), Increased hepatitis $E$ virus prevalence on Dutch pig farms from 33 to $55 \%$ by using appropriate internal quality controls for RT-PCR, J Virol Meth, 143, 112-116.

Sano D, Ueki Y, Watanabe T, and Omura T (2006), Membrane separation of indigenous noroviruses sewage sludge and treated wastewater, Wat Sci Tech, 54, 77-82.

Schvoerer E, Ventura M, Dubois O, Cazaux G, Serceau G, Gournier N, Dubois N V, Caminade P, Fleury H J A, and Lafon M E (2001), Qualitative and quantitative molecular detection of enteroviruses in water from bathing areas from as sewage treatment plant, Res Microbiol, 152, 179-186.

Schwab K J, Neill F H, Estes M K, Metcalf T G, and Atmar R L (1998), Distribution of Norwalk virus within shellfish following bioaccumulation and subsequent depuration by detection using RT-PCR, J Food Prot, 61, 1674-80.

Schwab K J (2007), Waterborne gastroenteritis viruses in: Human viruses in water, Bosch A (Ed) Perspective in Medical Virology, Zuckerman A J, and Mushahwar I K (eds), pp 27-38.

Sedmak G, Bina D, MacDonald J, and Couillard L (2005), Nine-year study of the occurrence of culturable viruses in source water for two drinking water treatment plants and the influent and effluent of a wastewater treatment plant in Milwaukee, Wisconsin (August 1994 through July 2003), Appl Environ Microbiol, 71, 1042-1050.

Shannon M A, Bohn P W, Elimelech M, Georgiadis J D, Marinas B J, and Mayes A M (2008), Science and technology for water purification in the coming decades, Nature, 452, 301-310.

Smiley J R, Hoet A E, Traven M, Tsunemitsu H, and Saif L J (2003), Reverse transcriptionPCR assays for detection of bovine enteric caliciviruses (BEC) and analysis of the genetic relationship among BEC and human caliciviruses, J Clin Microbiol, 41, 3089-3099.

Souza M, Azevedo MS, Jung K, Cheetham S, and Saif L J (2008), Pathogenesis and immune responses in gnotobiotic calves after infection with the genogroup II.4-HS66 strain of human norovirus, $J$ Virol, 82, 1777-1786.

Steyer A, Poljsak-Prijatelj M, Barlic-Maganja D, and Marin J (2008), Human, porcine and bovine rotaviruses in Slovenia: evidence of interspecies transmission and genome reassortment, J Gen Virol, 89, 1690-1698.

Symes S J, Gunesekere I C, Marshall J A, Wright P J (2007), Norovirus mixed infection in an oyster-associated outbreak: an opportunity for recombination, Arch Virol, 152, 1075-1086.

Takahashi M, Tanaka T, Azuma M, Kusano E, Aikawa T, Shibayama T, Yazaki Y, Mizuo H, Inoue J, and Okamoto H (2007), Prolonged fecal shedding of hepatitis E virus (HEV) during sporadic acute hepatitis E: evaluation of infectivity of HEV in fecal specimens in a cell culture system, J Clin Microbiol, 45, 3671-3679 
Tan $M$ and Jiang $X$ (2007), Norovirus-host interaction: implications for disease control and prevention, Expert Rev Mol Med, 9, DOI: 10.1017/S1462399407000348.

Tang Y W, Wang J X, Xu Z Y, Guo Y F, Qian W H, and Xu J X (1991), A serologically confirmed case control study of a large outbraks of hepatitis $A$ in China associated with consumption of clams, Epidemiol Inf, 107, 651-657.

Teunis P F M, Moe C L, Liu P, Miller S E, Lindesmith L, Baris R S, Le Pendu J, Calderon R L (2008), Norwalk virus: how infectious is it? J Med Virol, 80, 1468-1476.

Tian P, Engelbrektson A L, Jiang X, Zhong W, and Mandrell R E (2007), Norovirus recognizes histo-blood group antigens on gastronintestinal cells of clams, mussels, and oysters: a possible mechanism of bioaccumulation, J Food Prot, 70, 2140-2147.

Turcios R M, Widdowson M A, Sulka A C, Mead P S and Glass R L (2006), Revaluation of epidemiological criteria for identifying outbreak of acute gastroenteritis due to norovirus: United States, 1998-2000, Clin Infect Dis, 42, 964-969.

Ueki Y, Sano D, Watanabe T, Akiyama K, and Omura T (2005), Norovirus pathway in water environment estimated by genetic analysis of strains from patients of gastroenteritis, sewage, treated wastewater, river water and oysters, Wat Res, 39, 4271-4280.

Ueki Y, Shoji M, Suto A, Tanabe T, Okimura Y, Kikuchi Y, Saito N, Sano D, and Omura T (2007), Persistence of caliciviruses in artificially contaminated oysters during depuration, Appl Environ Microbiol, 73, 5698-5701.

Umesha K R, Bhavani N C, Venugopal M N, Karunasagar I, Krohne G, and Karunasagar I (2008), Prevalence of human pathogenic enteric viruses in bivalve molluscan shellfish and cultured shrimp in south west coast of India, Int J Food Microbiol, 122, 279-286.

van der Berg H, Lodder W, van der Poel W, Vennema H, and de Roda-Husman A M (2005), Genetic diversity of noroviruses in raw and treated sewage water, Res Microbiol, 156, 532540.

van der Poel W H M, Vinje J, van der Heide R, Herrera M I, Vivo A, and Koopmans M P G (2000), Norwalk-like calicivirus genes in farm animals, Emerg Inf Dis, 6, 36-41.

Wait D A, and Sobsey M D (2001), Comparative survival of enteric viruses and bacteria in Atlantic Ocean seawater, Wat Sci Tech, 43, 139-142.

Wang Q-H, Chang K-O, Cheetham M G, Souza M, Funk J A, and Saif L J (2005), Porcine noroviruses related to human noroviruses, Emerg Inf Dis, 11, 1874-1881.

Wang Q-H, Souza M, Funk J A, Zhang W, and Saif L J (2006), Prevalence of noroviruses and sapoviruses in swine of various ages determined by reverse transcription-PCR and microwell hybridization assays, J Clin Microbiol, 44, 2057-2062.

Ward P, Muller P, Letellier A, Quessy S, Simard C, Trottier Y-L, Houde A, and Brassard J (2008), Molecular characterization of Hepatitis $E$ viruses detected in swine farms in the province of Quebec, Can J Vet Res, 72, 27-31.

Westrell, T, Teunis $P$, van den Berg H, Lodder W, Ketelaars H, Stenstrom T A, and de Roda Husman A M (2006), Short- and long-term variations of norovirus concentrations in the Meuse river during a 2-year study period, Water Res, 40, 2613-2620.

Wold W S M and Horwitz M S (2007), Adenoviruses, in: Fields Virology, Knipe D M, Howley $\mathrm{P}$ M, (Eds), Baltimore, pp 2395-2436.

Wyne-Jones $P$ (2007), The detection of waterborne viruses, in: Human viruses in water, Bosch A (Ed) Perspective in Medical Virology, Zuckerman A J, and Mushahwar I K (eds), pp 177-226.

Yamashita T, Sugiyama M, Tsuzuki H, Sakae K, Suzuki Y, and Miyazaki Y (2000), Application of a reverse transcription-PCR for identification and differentiation of Aichi virus, a new member of the picornavirus family associated with gastroenteritis in humans, $\mathrm{J}$ Clin Microbiol, 38, 2955-2961.

Zheng D-P, Ando T, Fankhauser R L, Beard R S, Glass R, and Monroe S S (2006), Norovirus classification and proposed strain nomenclature, Virology, 346, 312-323. 


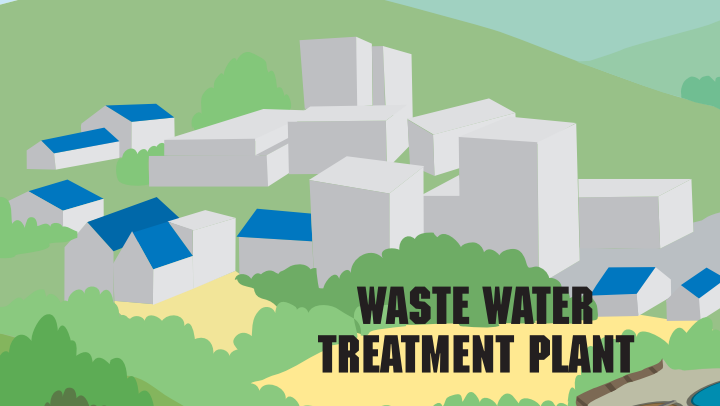

\section{manc \\ $\rightarrow \infty$ \\ CMTCHMENT AREA}

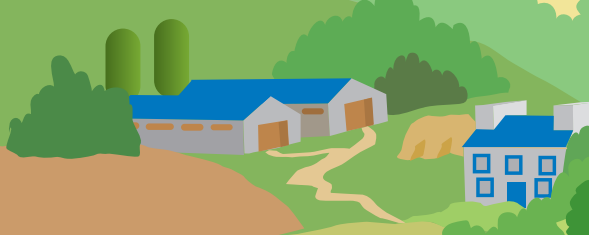

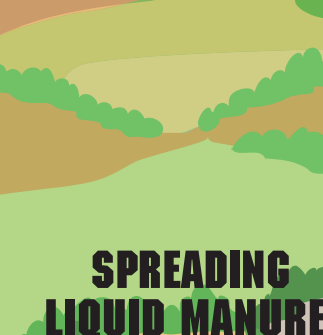

LIQUID MANURES

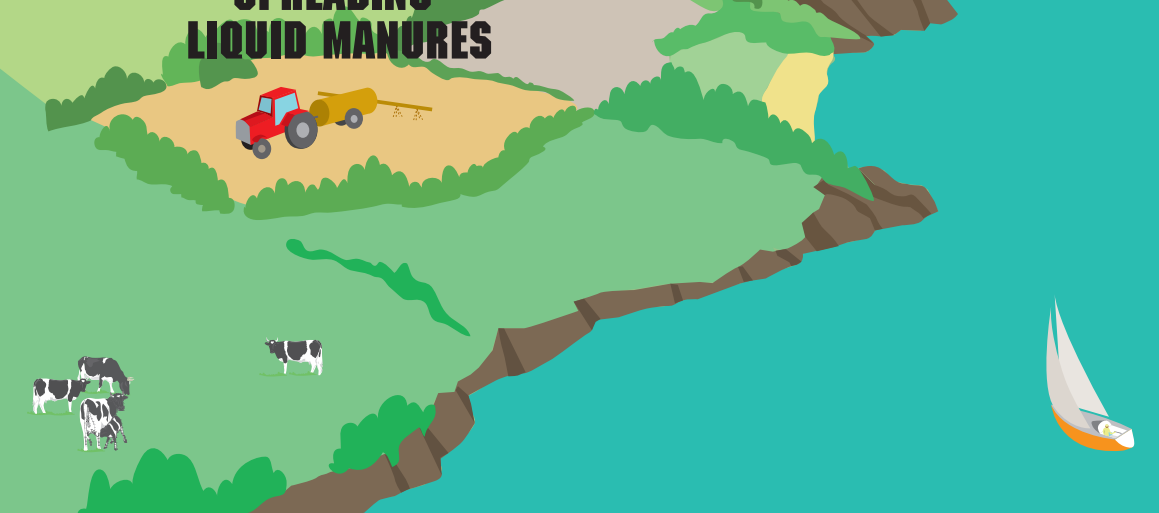
AGRICULTURE AMD URBAM AGTIVIIIIES

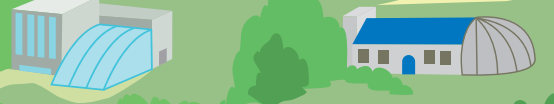

SHELLFISH FARM WASTES

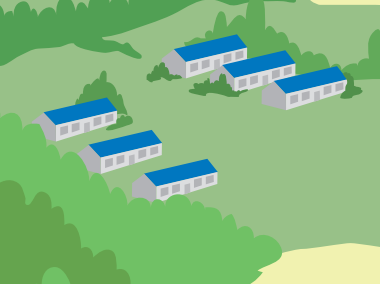

4

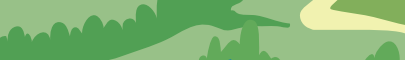

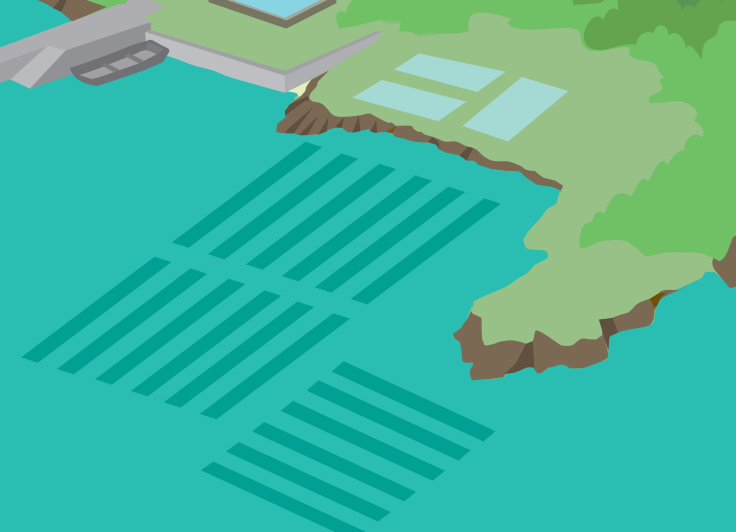
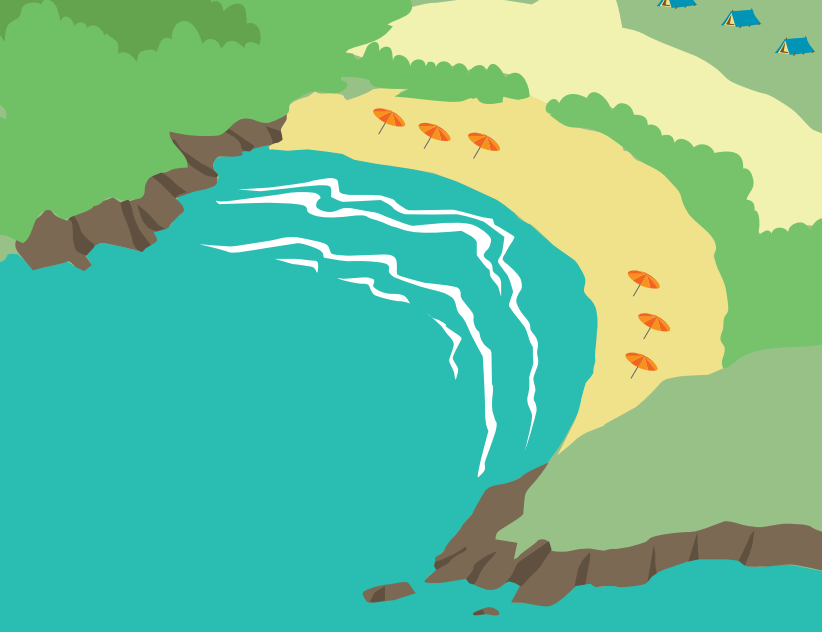
Table 1: Characteristics of the the main enteric viruses.

\begin{tabular}{|c|c|c|c|c|c|c|c|}
\hline name & Adenovirus & Aichi virus & Astrovirus & calicivirus & enterovirus & rotavirus & Hepatitis A virus \\
\hline Size & $70 \mathrm{~nm}$ & $27-32 \mathrm{~nm}$ & $27-32 \mathrm{~nm}$ & $27-32 \mathrm{~nm}$ & $20-30 \mathrm{~nm}$ & $70 \mathrm{~nm}$ & $27-32 \mathrm{~nm}$ \\
\hline Capside & Complexe & icosahedral & icosahedral & icosahedral & icosahedral & $\begin{array}{l}\text { Triple layer } \\
\text { icosahedral }\end{array}$ & icosahedral \\
\hline Genome & dsDNA & ssRNA & ssRNA & ssRNA & ssRNA & dsRNA & ssRNA \\
\hline $\begin{array}{l}\text { Size } \\
\text { genome }\end{array}$ & $\begin{array}{l}35,900 \text { bases } \\
\text { pair }\end{array}$ & 8,251 bases & 6,797 bases & 7,642 bases & 7,200 bases & $\begin{array}{l}11 \text { genes (3302 to } \\
667 \mathrm{bp)}\end{array}$ & 7478 bases \\
\hline $\begin{array}{l}\text { incubation } \\
\text { illness }\end{array}$ & $\begin{array}{l}\text { 3-10 days } \\
\text { gastroenteritis }\end{array}$ & $\begin{array}{l}\text { 1-2 days } \\
\text { gastroenteritis }\end{array}$ & $\begin{array}{l}\text { 3-5 days } \\
\text { gastroenteritis }\end{array}$ & $\begin{array}{l}2-3 \text { days } \\
\text { gastroenteritis }\end{array}$ & $\begin{array}{l}\text { 7-30 days } \\
\text { diverse }\end{array}$ & $\begin{array}{l}3 \text { days } \\
\text { gastroenteritis }\end{array}$ & $\begin{array}{l}\text { Up to } 6 \text { weeks } \\
\text { hepatitis }\end{array}$ \\
\hline age & Young children & Young adults & children & All ages & All ages & Young children & All ages \\
\hline
\end{tabular}


Table 2: Titers of enteric viruses in stool specimens

\begin{tabular}{lccl}
\hline Virus & $\begin{array}{c}\text { Range of virus concentrations } \\
\text { (RNA copies/g) } \\
\text { maximal }\end{array}$ & References \\
\hline HAV & $3.4 \times 10^{5}$ & $5.6 \times 10^{11}$ & Costafreda et al., 2006 \\
HEV & $<10^{2}$ & $10^{7}$ & Takahashi et al., 2007 \\
Rotavirus & $10^{3}$ & $10^{10}$ & Freeman et al., 2008 \\
NoV & $1.4 \times 10^{7}$ & $4.2 \times 10^{9}$ & Ludwig et al., 2008 \\
& $10^{8}$ & $10^{12}$ & Lee et al., 2007 \\
& $2.2 \times 10^{4}$ & $10^{11}$ & Chan et al., 2006 \\
& $9 \times 10^{7}$ & $6 \times 10^{10}$ & Kageyama et al., 2003 \\
& $5 \times 10^{8}$ & $1.6 \times 10^{12}$ & Atmar et al., 2008 \\
$\mathrm{SaV}$ & $1.3 \times 10^{5}$ & $2.1 \times 10^{10}$ & Oka et al., 2006 \\
\hline
\end{tabular}


Table 3: Average concentration of human enteric viruses detected in treated wastewater samples

\begin{tabular}{|c|c|c|c|c|}
\hline Virus & $\begin{array}{l}\text { positive sample } \\
\text { (\%) }\end{array}$ & $\begin{array}{l}\text { Average concentration } \\
\text { PCR units/L }\end{array}$ & $\mathrm{PFU} / \mathrm{L}$ & reference \\
\hline HAV & 100 & $9 \times 10^{1}-3.5 \times 10^{3}$ & & Brooks et al., 2005 \\
\hline NoV & $\begin{array}{l}93 \\
7 \\
53 \\
100 \\
100 \\
38 \\
100\end{array}$ & $\begin{array}{l}<10^{1}-3 \times 10^{4} \\
0-1.6 \times 10^{5} \\
1.8 \times 10^{4}-9.7 \times 10^{5} \\
8.7 \times 10^{1}-2.9 \times 10^{3} \\
6 \times 10^{2}-2.4 \times 10^{4} \\
2.1 \times 10^{2}-6 \times 10^{6} \\
6-6.4 \times 10^{3}\end{array}$ & & $\begin{array}{l}\text { Van der Berg et al., } 2005 \\
\text { Laverick et al., } 2004 \\
\text { Pusch et al., } 2005 \\
\text { Katayama et al., } 2008 \\
\text { Lodder and de Roda-Husman, } 2005 \\
\text { Da Silva et al., } 2007 \\
\text { Haramoto et al., } 2006\end{array}$ \\
\hline $\begin{array}{l}\mathrm{SaV} \\
\mathrm{AV}\end{array}$ & $\begin{array}{l}58 \\
40 \\
50 \\
82\end{array}$ & $\begin{array}{l}0.5-1.8 \times 10^{2} \\
3,7 \times 10^{3}-1.2 \times 10^{5} \\
1.1 \times 10^{3}-6.2 \times 10^{5} \\
8 \times 10^{2}-5 \times 10^{5}\end{array}$ & & $\begin{array}{l}\text { Haramoto et al., } 2008 \\
\text { Pusch et al., 2005 } \\
\text { El-Senousy et al, } 2007 \\
\text { Le Cann et al., } 2004\end{array}$ \\
\hline EV & $\begin{array}{l}90 \\
100 \\
100\end{array}$ & $\begin{array}{l}10^{1}-5.4 \times 10^{4} \\
4 \times 10^{0}-1.7 \times 10^{2}\end{array}$ & $5-92$ & $\begin{array}{l}\text { Schvoerer et al., } 2001 \\
\text { Lodder and de Roda-Husman, } 2005 \\
\text { Katayama et al. } 2008\end{array}$ \\
\hline $\mathrm{AdV}$ & 100 & $9 \times 10^{2}-5 \times 10^{4}$ & & Katayama et al., 2008 \\
\hline Reo & 90 & & 1-233 (MPN) & Sedmak et al., 2005 \\
\hline
\end{tabular}


Table 4: Efficiency of different waste water treatment plant to remove norovirus.

\begin{tabular}{llcl}
\hline Treatment & genogroups & $\log _{10}$ reduction value. & References \\
\hline Physical treatment & GI & $1.82( \pm 0.61)$ & Haramoto et al., 2006. \\
& GII & $2.74( \pm 1.10)$ & \\
Chemical treatment & GI & $0.45( \pm 0.49)$ & Haramoto et al., 2006. \\
(chlorination) & GII & $0.95( \pm 1.80)$ & \\
Tertiary filtration & GI \& GII & $0.50( \pm 0.84)$ & Ottoson et al., 2006 \\
Membrane Bioreactor & GI \& GII & $1.14( \pm 0.88)$ & Ottoson et al., 2006 \\
Activated sludge treatment & GI \& GII & $2-2.7$ & van der Berg et al., 2005 \\
Wastewater Stabilized & GI & $0-3^{*}$ & Da Sylva et al., 2007 \\
Pounds & GII & $0-5^{*}$ & \\
Membrane separation & GI \& GII & $2.9-3.5$ & Sano et al., 2006 \\
\hline
\end{tabular}

* depending on the residence time 
Table 5: human enteric viruses and phages detection in shellfish samples.

\begin{tabular}{lllllllll}
\hline Country & Shellfish & class & $\begin{array}{l}\text { \# of } \\
\text { sample }\end{array}$ & Phages & NoV & HAV & EV & Reference \\
\hline UK & oysters & A & 134 & 50 & 62 & - & - & Dore et al., 2000 \\
Italy & mussels & A & 36 & 8 & - & 14 & 36 & Croci et al., 2000 \\
Norway & mussels & A & 681 & 23.8 & 6.8 & & & Myrmel et al., 2004 \\
Spain & mussels & A & 7 & 14 & - & 0 & 0 & Munian-Mujika et al., 2003 \\
& & B & 36 & 22 & - & 22 & 25 & \\
\multirow{5}{*}{ Netherlands } & Oysters & B & 11 & 36 & - & 18 & 9 & \\
India & Oysters & A & 22 & 100 & 0 & 0 & 27 & Lodder-Verschoor et al., 2005 \\
& Oysters & B & 100 & 57 & 0 & 0 & 37 & Umesha et al., 2008 \\
\hline
\end{tabular}

Phages and viruses expressed in \% 
Table 6: Effects of different physical factors on virus inactivation in shellfish.

\begin{tabular}{|c|c|c|c|c|c|c|}
\hline Treatment & Shellfish & Recipe & Virus & contamination & Persistence of virus & Reference \\
\hline \multirow[t]{17}{*}{ Heat } & \multirow[t]{4}{*}{ Oysters } & Stewed in milk & poliovirus & Seeded & $10 \%$ survival after $8 \mathrm{~min}$ & Di Girolamo et al., 1970 \\
\hline & & Fried/oil $177^{\circ} \mathrm{C}$ & poliovirus & Seeded & $10 \%$ survival after $8 \mathrm{~min}$. & Di Girolamo et al., 1970 \\
\hline & & Baked /oven $121^{\circ} \mathrm{C}$ & poliovirus & Seeded & $13 \%$ survival after $20 \mathrm{~min}$. & Di Girolamo et al., 1970 \\
\hline & & Steamed & poliovirus & Bioaccumulated & $7 \%$ survival after $30 \mathrm{~min}$. & Di Girolamo et al., 1970 \\
\hline & \multirow[t]{11}{*}{ Mussels } & \multirow[t]{2}{*}{ Boiling } & HAV & \multirow[t]{2}{*}{ Seeded } & No survival after 3 min for HAV & \multirow[t]{2}{*}{ Hewit and Greening, 2006} \\
\hline & & & norovirus & & $100 \%$ persistence for NoV RNA & \\
\hline & & \multirow[t]{2}{*}{ Steamed } & HAV & \multirow[t]{2}{*}{ Bioaccumulated } & $0.1 \%$ survival after 5 min. & \multirow[t]{2}{*}{ Abad et al. 1997} \\
\hline & & & rotavirus & & $0.1 \%$ survival after 5 min. & \\
\hline & & \multirow[t]{2}{*}{ Steamed } & HAV & \multirow[t]{2}{*}{ Seeded } & No survival after 3 min for HAV & \multirow[t]{2}{*}{ Hewit and Greening, 2006} \\
\hline & & & norovirus & & $100 \%$ persistence for NoV RNA & \\
\hline & & \multirow[t]{2}{*}{ in hors d'oeuvre } & HAV & \multirow[t]{2}{*}{ Bioaccumulated } & Infectious viruses detected after 9 & \multirow[t]{2}{*}{ Croci et al., 2005} \\
\hline & & & & & $\min *$ & \\
\hline & & \multirow[t]{2}{*}{ au gratin } & \multirow[t]{2}{*}{ HAV } & \multirow[t]{2}{*}{ Bioaccumulated } & Infectious viruses detected after 5 & \multirow[t]{2}{*}{ Croci et al., 2005} \\
\hline & & & & & $\min *$ & \\
\hline & & in tomato sauce & HAV & Bioaccumulated & No survival after 8 min. & Croci et al., 2005 \\
\hline & \multirow[t]{2}{*}{ Cockles } & \multirow[t]{2}{*}{ Boiling } & poliovirus & \multirow[t]{2}{*}{ Bioaccumulated } & No survival after 3 min. & \multirow[t]{2}{*}{ Millard et al. 1987} \\
\hline & & & HAV & & No survival after 2 min. & \\
\hline
\end{tabular}




\begin{tabular}{|c|c|c|c|c|c|c|}
\hline Cold & Oyster & kept at $5^{\circ} \mathrm{C}$ & poliovirus & Bioaccumulated & $13 \%$ survival after 1 month & Di Giralimo et al., 1970 \\
\hline & & Frozen o $\left(-17.5^{\circ} \mathrm{C}\right)$ & poliovirus & Bioaccumulated & $10 \%$ survival after 12 weeks & Di Giralimo et al., 1970 \\
\hline Marinade & Mussels & $\begin{array}{l}\text { Steamed and } \\
\text { marination (pH 3,75) }\end{array}$ & $\begin{array}{c}\text { HAV } \\
\text { norovirus }\end{array}$ & Seeded & $\begin{array}{l}3 \% \text { survival after } 4 \text { weeks for HAV } \\
100 \% \text { persistence for NoV RNA }\end{array}$ & Hewit and Greening, 2004 \\
\hline $\begin{array}{c}\text { High } \\
\text { pressure }\end{array}$ & oysters & & $\begin{array}{l}\text { Murine } \\
\text { Nrovirus }\end{array}$ & Bioaccumulated & $\begin{array}{l}\text { No survival after } 5 \text { min at } 5^{\circ} \text { at } 325 \\
\qquad \mathrm{MPa}\end{array}$ & Kingsley et al., 2002 \\
\hline & oysters & & HAV & Bioaccumulated & $0.1 \%$ survival after $1 \mathrm{~min}$ at $400 \mathrm{MPa}$ & Calci et al., 2005 \\
\hline
\end{tabular}

*: infectious virus too low for quantification 